\title{
TOPLU TAŞIMA HİZMETİNDE ÖRGÜTSEL STRES KAYNAKLARI VE ÇÖZÜM ÖNERILERI'1
}

\author{
Mehmet Zennur GÜRBÜZ² \\ Göknur Arzu AKYÜZ3
}

\author{
Received (Başvuru Tarihi): 31/03/2017 \\ Accepted (Kabul Tarihi): 20/06/2017
}

Published Date (Yayın Tarihi): 15/09/2017

Öz

Örgütsel stres, gerek çalışanlar gerek işletmeler açısından negatif sonuçlara neden olabilecek bir kavramdır. Bu çalışmanın amacı, toplu taşıma hizmetinde çalışan sürücülerin maruz kaldıkları örgütsel stres kaynaklarını tespit etmek, sınıflandırmak ve çeşitli önerilerde bulunmaktır. Örgütsel stres kaynakları ile ilgili kapsamlı bir literatür araştırması yapılmış, şu temel başlıklar tespit edilmiştir: işin yapısı, örgütsel yapı, örgütsel politika, örgüt içi ilişkiler, fiziksel koşullar. Geliştirilen ölçekle 2016 yılında EGO Genel Müdürlüğü toplu taşıma hizmetinde çalışan sürücülere bir anket uygulanmıştır. Ankara'daki tüm evrene (2.137 kişi) ulaşılarak geri dönüşü sağlanan 1.554 anketin verileri istatistiksel olarak analiz edilmiştir. Bu sayı evrenin $\% 72$ 'lik kısmını temsil etmektedir. SPSS (22.0) paket programı aracılı̆̆ıla betimsel istatistikler incelenmiş, faktör, güvenilirlik ve varyans analizleri yapılmıştır. Çalışma, sürücülerin orta derecede stres yaşadıklarını; en fazla stres oluşturan sebeplerin: "Maaş (ücret) adaletsizliği ve/veya düşüklüğü”, "Yolcuların sürücülere zorbalık yapması, sözlü tacizde bulunması ve/veya şiddet uygulaması” ile "Hizmet sözleşmesinin yenilenmemesi ya da iş̧ten çıkarllma korkusu” olduğunu ortaya koymuştur. Stres seviyelerinin sürücünün atandığl bölgeye göre önemli değişkenlik gösterdiği belirlenmiştir. Sürücülerde strese sebep olan etmenler ile ilgili gerekli önlemler alınarak, sürücülerin stres düzeylerinin düşürülmesi için öneriler yapılmıştır.

Anahtar Kelimeler: Örgütsel Stres, Stres Kaynaklarl, Toplu Taşıma

JEL Kodu: M10, M19

\section{ORGANIZATIONAL STRESS SOURCES AND SOLUTION PROPOSALS IN PUBLIC TRANSPORT}

\begin{abstract}
Organizational stress is a concept which can have negative effects for both the workers and the organizations. The purpose of this study is to determine and classify the organizational stress sources that public transportation is exposed to and to provide suggestions for managing these stress factors. A comprehensive literature survey is made in organizational stress factors and the following classes are identified: work struc ture, organizational structure, organizational policy, within-company relations and physical conditions. A questionnaire is developed for Ankara EGO General Directorate; applied to 2.137 drivers in Ankara in 2016 with a meaningful return of 1.554 data sets, representing $72 \%$ of the population and results are statistically analyzed. Descriptive statistics, factor analysis and related validity and regional variance analyses are performed by SPSS (22.0) software. The study revealed that: drivers are exposed to mid-level stress; and most critical stress causes are "injustice and/or insufficiency of salaries", "aggressive, violent behavior and verbal abuse of passengers towards drivers", "fear of losing jobs or renewal of the contract". A significant level of
\end{abstract}

\footnotetext{
${ }^{1}$ Bu çalışma, ilk yazarın Yüksek Lisans Tezinden üretilmiştir.

${ }^{2}$ EGO Genel Müdürlüğü, m.z.gurbuz@hotmail.com

${ }^{3}$ Yrd. Doç. Dr., Türk Hava Kurumu Üniversitesi, gaakyuz@ thk.edu.tr
} 
variation in stress levels is identified with respect to different regions of Ankara where drivers are assigned. Suggestions are made in relation to different stress causes to lower the stress levels exposed.

Keywords: Organizational Stress, Stress Sources, Public Transport

Jel Classification: M10, M19

\section{GíRiş}

Stres, günümüz toplumunun en yaygin sorunlarından biri haline gelmiş ve yoğunluğuna göre her ne kadar bireylere ve örgütlere yararlı olabilse de sonuçları itibariyle genellikle zararh olan bir kavramdır. Aşırı stres bireylerin yaşam kalitesini azaltmakta, psikolojisini bozmakta, performansını düşürmekte, çeşitli hastalıklara ve kazalara sebep olmakta, insanlar arasındaki sosyal ilişkileri bozmaktadır. İş hayatında ise devamsızlğa, verim düşüklüğüne, iş kazalarına, kalite düşüklüğüne sebep olmaktadır (Gümüşstekin, v.d, 2004:65). Günümüz modern toplumunda günlük yaşamlarının önemli bir kısmını iş ortamında geçiren bireyler; işin yapısından, fiziksel koşullardan, örgütsel politikalardan, örgüt içi ilişkilerden kaynaklı stres yaşamaktadırlar (Poyraz, 2009: 26-35).

$\mathrm{Bu}$ çalşsmanın amacı, büyükşehirlerde toplu taşıma hizmetinde çalş̧an sürücülerin, çalşma ortamında maruz kaldkları stres kaynaklarının tespit etmek ve sınıflandırmak, stres algilarının ne olduğunu bulmak ve stresi nasıl yönetebilecekleri ile ilgili öneriler geliştirmektir.

Örgütlerde aşırı stres; çalışıldığı yerin özelliğine göre işletmelere büyük zararlar verebilir, ayrıca sunulan hizmetten faydalanan insanlara telafisi mümkün olmayan sonuçlar doğurabilir. Özellikle büyükşehirlerde günde binlerce yolcunun faydalandığı toplu taşıma hizmetinde çalşan sürücülerin stres düzeyleri, yolcuların can ve mal güvenliği için hayati önem arz etmektedir.

Çalşsma kapsamıa; Ankara Büyükşsehir Belediyesi EGO Genel Müdürlüğü toplu taşıma hizmetinde çahışan tüm sürücüler dâhil edilmiştir. EGO Genel Müdürlüğ̈; Ankara'da toplu taşıma hizmeti ulaştırdı̆̆ yerleri ilçelere göre 5 Bölge Şube Müdürlüğüne ayrrmış olup, bu bölgelerde çalşan toplam 2.137 sürücünün tamamına ulaşılmıştır. Bu çalşmada örneklem alınmamıştır.

$\mathrm{Bu}$ çalışmada; öncelikle literatür taraması yapılmış ve stres kaynaklarından olan bireysel stres kaynakları, çevresel stres kaynakları ve örgütsel stres kaynakları tartısılmışıtır. Daha sonra kullanılan araştırma metodolojisi ve araştırma sorularına yer verilmiş olup, ayrıca sürücülerin örgütsel stres düzeylerini ölçmek amaciyla hazırlanan anket çalışması ve bu anket sonucunda elde edilen verilerin SPSS (22.0) paket programı aracilı̆ıyla yapılan istatistiksel 
analizleri ve bulguları sunulmuştur. Toplu taşıma hizmetinde çahşan sürücülere uygulanan anket çalışmasının sonuçları değerlendirilmiş, ayrıca örgütsel stres kaynaklarının yönetimi ile ilgili hem uygulayıcılara hem de araştırmacılara yönelik öneriler getirilmiştir.

\section{STRES VE STRES KAYNAKLARI}

Stres; çevresi ile uyum içinde yaşayan bireyi tehdit edici, rahatsılzlk verici ya da sıkıntıya düşürücü dıssal etkenlerin varlığ durumunda bireyin fizyolojik ve psikolojik olarak duruma tepki göstermesi olarak tanımlanabilir (Budak, 2001: 704). Literatürde, stres kaynakları farkh ana başlklar altında gruplandırılmaktadır (Bakırcı, 2012: 20; Balcı, 2014: 31; Erdal, 2009: 40; Özalp, 2014: 17).

Stres kaynakları ile ilgili literatürde standart bir smnflandırma olmamasma rağmen; bireysel, çevresel, örgütsel stres kaynakları üzerinde durulmaktadır (Seyhan, 2007:15; Balc1, 2014:25; Güçlü, 2001:96). Bireysel stres kaynakları bireyin kişilik özelliklerinden ve yaşam biçiminden kaynaklanan stres kaynaklarıdır ve stresin kaynağı bireyin kendisidir. Kişilik (Sabuncuoğlu, 2001:240), yaş (Seyhan, 2007: 17), cinsiyet (Balc1, 2014:29), aile yapıs1 (Ekinci v.d., 2003:102), ekonomik sorunlar (Eroğlu, 2000:385; Erdal, 2009: 38-39) bu kaynaklardan sayılabilir. Çevresel stres kaynakları bireyin kendisinden bağımsız olarak günlük hayatta karşılaştığı ekonomik krizler, işsizlik, enflasyon, kentleşmeden kaynaklı ulaşım sorunları, çevre kirliliği, yeşil alanların yok edilmesi, hızh teknolojik değişimler, kültürel yozlaşma gibi etkenlerdir. Genel ekonomik sorunlar (Eren, 2015:283), kentsel sorunlar (Saygll, 1996: 10-11), sosyal ve kültürel değişimler (Okutan, v.d. 2002:22) olarak detaylandırılabilir. Örgütsel stres kaynakları ise, zamanının çoğunu iş ortamında geçiren bireyin maruz kaldığı örgüt kaynakh çeşitli stres yaratan faktörlerdir. Literatürde iş stresi, meslek stresi olarak da adlandırılan örgütsel stres; çalıştıkları örgüte veya yaptıkları işe ilişkin çalşanların istemlerinin yeterli düzeyde karşılanmamasını iş görenlerde yarattığı tepki olarak tanımlanabilir (Aslan, 1995: 22).

Çalş̧ma kapsamında örgütsel stres faktörlerine odaklanılmış ve taksonomi yöntemiyle kapsamlı bir literatür taraması yapılmıştır. $\mathrm{Bu}$ yöntemde, literatürün etkin bir şekilde sinıflanması ve mevcut literatürdeki ortaklkkların ve farkllıkların sınıflanması amaçlanır (Reisman, 1992). Çalışmada toplamda; 1986-2016 yllları arasında 18 Kitap, 15 Tez ve 10 Makale olmak üzere 43 kaynak incelenmiştir. Kaynakların yayınlanma tarihi, yazarı, konusu, türü Tablo 1. (Ek-1) de verilmiştir. Literatürde örgütsel stres kaynakları ile ilgili çeşitli nitel ve nicel çalışmalara yer verildiği görülmektedir. Örgütten kaynaklı stres faktörleri genel 
olabileceği gibi yapılan işe özgü faktörler de olabilmektedir. Örgütsel stres genellikle; aşırı iş yükü, çalışanlar arası aşırı rekabet, dedikodu, ast-üst çatışması, kötü fiziksel koşullar ve olumsuz örgütsel politikalardan kaynaklanmaktadır (Ertekin, 1993:7).

Bazı çalışmalarda; örgütsel stres faktörleri üst başlk-alt başlik ayrımına gitmeden maddeler halinde sıralanmıştır (Aydın, 2012: 17-26; Turna, 2014:38-46; Gamsı, 2013: 3435). Bazı çalışmalarda ise; işin yapısı, fiziksel koşullar, örgütsel politika, örgüt içi ilişkiler gibi alt başliklar altında detaylandırmışır (Poyraz, 2009: 26-35; Özalp, 2014: 17-30; Merkan, 2011: 16-21; Bakirc1, 2012: 20; Balc1, 2014: 31; Erdal, 2009: 40; Özalp, 2014: 17).

Y1lmaz (2006: 33) çahı̧masında örgütsel stres kaynaklarını şu ana başlklar altında detaylandırmışır: (a) işin özellikleri ile ilgili kaynaklar, (b) örgütsel rolle ilgili kaynaklar, (c) işteki ilişkilerle ilgili kaynaklar, (d) örgüt yapısı ve iklimiyle ilgili kaynaklar, (e) insan kaynakları yönetimiyle ilgili kaynaklar. Bakırcı (2012: 23-24), fiziksel koşullar, örgütsel politikalar, örgütsel yapı, örgütsel süreç, kişisel etkenli koşullar şeklinde bir sinıflama ortaya koymuştur. Gümüştekin (2004:65) ise örgütsel stres kaynakları şu ana başlıklar altında sınıflandırmıştır: İşin yapısına ilişkin stres kaynakları, örgüt içindeki ilişkiler ile ilgili stres kaynakları, örgütsel yapıya ilişkin stres kaynakları, örgütsel politikalar ve ücret eşitsizliklerine ilişkin stres kaynakları, iş ortamındaki fiziksel şartlara ilişkin stres kaynakları, örgütsel stresin diğer kaynakları. Michie (2002:68) ise örgütsel stres faktörlerini şu şekilde gruplandırmıştır: İşin yapısı, Örgütte üstlenilen rol, Kariyer geliştirme olanakları, Örgüt içi ilişkiler ve Örgütsel yap1.

Taksonomi çalışması doğrultusunda bu araştırmada örgütsel stres kaynakları Tablo 2'de görüldüğü üzere beş ana başlıkta (işin yapısı, örgütsel yapı, örgütsel politika, örgüt içi ilişkiler, fiziksel koşullar) sınıflandırılmış olup Tablo 2 (Ek-2) de detaylandırılmış ve aşağıda tartışılmıştır:

İşin yapısı: Bireylerin çalışı̆̆ı iş alanlarında; işin niteliğinden, kapsamından, yapısından kaynaklı stres yapıcilar vardır. Monotonluk (Şimşek, v.d. 2008: 339), işte tehlike unsurunun varlığı (Stora, 1994: 46), aşırı iş yükü ya da az çalşsma (Cam, 2004: 3-4; Bhatti, 2010:5), yeni teknoloji (Tutar, 2016: 241), çalşsma saatlerinin uzun olması (Yılmaz, v.d., 2006: 35-36) işin yapısından kaynaklı stresörler olarak sayılabilir (Poyraz, 2009: 27).

Örgütsel yapı: Örgütün yapısı da bazı durumlarda çalısanlarda stres kaynağı olabilmektedir. Merkezi yönetim modelini seçen işletmelerde birbirine bağıml olan birimler arasinda var olan rekabet ya da idareciler tarafindan verilen kararlara katilmama sonucunda 
çalı̧anlarda örgütsel yapıdan kaynakh stres ortaya çıkabilmektedir (Bayram, 2006:36; Rawshan, 1998:41). Örgütsel yapıda; Kararlara katılmama (Altuntaş, 2003:126; Balcı, 2014: 41-42), hiyerarşik ve merkezi yap1 (Genç, 2005: 270; Cam, 2004: 5), yetki ve sorumluluklar arasında uyumsuzluk (Aydın, 2008:51-52; Okutan, v.d., 2002: 8) gibi etkenler örgütsel yapıdan kaynaklanan stresörlerdir.

Örgütsel politikalar: Örgütlerin belirlemiş oldukları politikalar ve yönetim tarzları da çalşanlarda stres yaratacak faktörler içermektedir. Maaş adaletsizliği (Gürün, 2009:86), maaş düşüklüğ̈̈ (Baltaş v.d., 2008:82), adaletsiz ödül, terfi ve başarı değerlendirmeleri (Kaya, 2006:44; Palmer, v.d., 1993:29), örgüt yapısındaki rol, görev ve sorumluluklarm dağglımındaki bozukluklar (Tutar, 2016:249; Güney, 2006:333; Barutçugil, 2002:160), örgütün yanlşs yönetilmesi, örgütün yapısı, hedefleri, vizyonu ve misyonu ile ilgili belirsizliklerin olması, üst yöneticilerin keyfi uygulamaları, çalşanların görev tanımlarmın olmaması ya da sk sk değiştirilmesi, adaletsiz yönetim, denetim ve performans değerlendirmeleri, aşırı merkeziyetçilik ve bürokrasi gibi faktörler de çalışanları olumsuz etkilemekte ve stres yaşamalarına sebep olmaktadır (Aydın, 2012:22).

Örgüt içi ilişkiler: Çalşanlar arasında yeterli düzeyde iletişimin olmaması, işletmelerde huzursuzluğa ve verimsizliğe sebep olur. Çalşanlar yaptıkları işte takdir edilmeyi beklerler, yaptığı iş karşısında takdir edilen çalışanlar daha verimli olurken, performansları da artar (Arslan, 2010:22). Örgütte çalışanlar arasındaki kötü ilişsiler, iletişim güçlüğü ya da yetersiz iletişim (Balc1, 2014:39; Can, 2011:367), iş ortamında dedikodunun var olması, sosyal ilişkilerin azlı̆ğ, üstler-astlar ve meslektaşlar arasında zorbalı, taciz ve şiddetin olması, iftira, mobbing (Tutar, 2016:238; Yavuz, 2013:68), örgüt içi ilişkilerden kaynaklı stres faktörü olarak sayllabilir.

Fiziksel koşullar: Çalışılan ortamın sicaklığı-soğukluğu (Sandıç̧ı, 2010:6), aydınlatması (Eren, 2015:279), temizliği, çalışlan işyerinin aşırı büyük ya da küçük olması, aşırı ses ve gürülttü (Sabuncuoğlu, 1987:235; Sabuncuoğlu, 1986:55), işyerinin uzaklı̆̆, işyerine ulaşım güçlüğü (Eren, 2015:268), iş için gerekli araç-gereç, laboratuar eksikliği, zehirli kimyasallar ve radyasyon gibi durumlar (Soysal, 2009:21, Camkurt, 2007:93-103) fiziksel şartlardan kaynaklı stres faktörleri olarak sayılabilir. Toplu taşıma hizmetinde sürücüler; hem genel örgütsel stres faktörleriyle, hem de yaptıkları işe özgü stres faktörleri ile karşılaşabilmektedir Dolayısıyla aşağıda literatürden gelen beşli sınıflama doğrultusunda, ilgili kurumun yöneticisi ve sürücüleriyle yapılan görüşmelerle sürücülerin çalşsma koşulları 
da göz önüne alnarak, sürücüleri etkileyen örgütsel stres faktörleri alt boyutlarryla tespit edilmiş olup, Tablo 3 ’te gösterilmiştir.

Tablo 3: Toplu Taşımada Sürücüleri Etkileyen Örgütsel Stres Kaynakları

\begin{tabular}{|c|c|}
\hline \multicolumn{2}{|r|}{ Örgüts el Stres Kaynakları } \\
\hline İşin Yapısı & $\begin{array}{l}\text {-İşin monoton ve sıkıcı olması. } \\
\text {-Çalışma saatlerinin uzun olması. } \\
\text {-Servise zamanında başlama-bitirme baskısının olması. } \\
\text {-İstirahat sürelerinin az olması. } \\
\text {-Aşırı iş yükünün olması. } \\
\text {-Vatandaş memnuniyetsizliği ve şikâyet edilme korkusunun olması. } \\
\text {-Sürekli diğer insanlarla ve problemlerle uğraşmak durumunda kalmaları. } \\
\text {-Sorumlulukların ağır ya da çok olması. }\end{array}$ \\
\hline Örgütsel Yapı & $\begin{array}{l}\text {-Yapılan işle ilgili kararlara katılamamak. } \\
\text {-Yetki ve sorumluluklar arasında uyumsuzluk olması. } \\
\text {-Kişiler ve bölümler arası aşırı rekabet varlığı. } \\
\text {-Örgütün yanlış yönetilmesi. } \\
\text {-Örgüt yapısında rol, görev ve sorumlulukların dağılımındaki bozuklukların varlığı. }\end{array}$ \\
\hline Örgütsel Politika & $\begin{array}{l}\text {-Maaş (ücret) adaletsizliği veya düşüklüğ̈̈nün olması. } \\
\text {-Adaletsiz ödül, terfi ve başarı değerlemelerin varlığı. } \\
\text {-Sık sık görev yerinin değiştirilmesi. } \\
\text {-Kendini geliştirme olanaklarının azlığı. } \\
\text {-Kurumun sıkı kontrol ve denetimlerinin varlığ1. } \\
\text {-Cezalandırıcı değerlendirme sisteminin varlığı. } \\
\text {-Hizmet sözleşmesinin yenilenmeme/işten çıkarılma korkusunun olması. } \\
\text {-İşle ilgili yeterli eğitimin verilmemesi. } \\
\text {-Kaza anı ve sonrasında yeterli hukuki yardımın alınamaması. }\end{array}$ \\
\hline $\begin{array}{l}\text { Örgüt İçi } \\
\text { Illişkiler }\end{array}$ & $\begin{array}{l}\text {-Yapılan işte takdir edilmemek. } \\
\text {-İş yerinde dedikodunun varlığı. } \\
\text {-Amirler ile iletişim güçlüğ̈̈/yetersiz iletişimin olması. } \\
\text {-İş ortamındaki sosyalilişkilerin az olması. } \\
\text {-Yolcuların zorbalı yapması, sözlü tacizde bulunması ve/veya şiddet uygulaması. } \\
\text {-İşyerinde ki sorunlar için amir desteğinin eksik olması. }\end{array}$ \\
\hline Fiziksel Koşullar & $\begin{array}{l}\text {-Kötü fiziksel çalışma koşulları (İş ortamının sıcaklığı, soğukluğu, aydınlatılması v.b.,) } \\
\text { varlığı. } \\
\text {-Otobüsün körüklü ya da solo olması. } \\
\text {-Otobüsün kalabalık olması. } \\
\text {-İşyerinin uzak olması ve ulaşım güçlüğü. }\end{array}$ \\
\hline
\end{tabular}

\section{ARAŞTIRMANIN AMACI}

Ankara Büyükşsehir Belediyesi EGO Genel Müdürlüğü toplu taşıma hizmetinde çalşan sürücülerin örgütsel stres kaynaklarıı belirlemek amacıyla yapılan bu araştırmada, aşağıdaki sorulara yanıt aranmıştır:

(a) Toplu taşıma hizmetinde çalşan sürücüler, işin yapısı boyutunda ne düzeyde stres yaşamaktadırlar?

(b) Toplu taşıma hizmetinde çahşan sürücüler, örgütün yapısı boyutunda ne düzeyde stres yaşamaktadırlar? 
(c) Toplu taşıma hizmetinde çalışan sürücüler, örgütsel politikalar boyutunda ne düzeyde stres yaşamaktadırlar?

(d) Toplu taşıma hizmetinde çalşan sürücüler, örgüt içi ilişkiler boyutunda ne düzeyde stres yaşamaktadırlar?

(e) Toplu taşıma hizmetinde çalşan sürücüler, fiziksel koşullar boyutunda ne düzeyde stres yaşamaktadırlar?

Ayrıca, çalışma kapsamına dahil edilen 5 bölgede yaşanan stres seviyelerinin, tüm bu boyutlarda anlamlı bir farklılık gösterip göstermediği sorusuna da cevap aranmıştır.

\section{ARAŞTIRMANIN YÖNTEMI}

$\mathrm{Bu}$ çalışmada betimsel analiz yöntemi kullanılmıştır. $\mathrm{Bu}$ yöntemde, elde edilen bulgular önce sistematik olarak betimlenir, smiflandırilır; daha sonra elde edilen veriler arasında neden-sonuç ilişkisi irdelenir, ortaya çıkan bulgular yorumlanır ve sonuçlar elde edilir (Altunışı, 2010:322). Araştırmada veri toplama aracı olarak anket tekniği kullanılmıştır. Örgütsel stres kaynakları ile ilgili ulaşlabilen yerli ve yabancı makale, tez, kitap gibi kaynaklar incelenerek, örgütsel stres kaynakları ile ilgili hazırlanan stres anketleri incelenmiştir (Bakırc1, 2012:93-95; Güney, 2015:102-103; Madenoğlu, 2010:114; Merkan, 2011:102; Özalp, 2014:107-110; Poyraz, 2009:104; Turna, 2014:118).

Ölçek geliştirme sürecinde, öncelikle EGO Genel Müdürlüğünde toplu taşıma hizmeti ile ilgilenen amir ve sürücülerle ön görüşmeler yapılmıştır. Tüm bu araştrrmaların neticesinde tarafsız, net ve kolay anlaşlabilen sorular içeren bir ölçek hazırlanmasına özen gösterilmiştir. Ankette yer alan sorular, bir önceki bölümde belirtilen 5'li smiflama doğrultusunda toplu taşıma hizmetinde çalşan sürücülerin stres kaynaklarını ölçecek şekilde düzenlenmiştir. Ankette sorulara verilen cevaplar 1'den (hiç) 5'e (Pek çok) kadar siralaması yapılarak Likert tipi 5'li ölçek kullanılmıştır. Araştırmada kullanılacak görüşme anketi için Ankara Büyükşsehir Belediyesi EGO Genel Müdürlüğünden gerekli resmi izinler alınmıştır.

Daha sonra her bir bölgeden 5 toplamda 25 sürücüye ön test (pilot) uygulanmış olup, elde edilen verilerin güvenirlilik analizleri yapılmıştır. Güvenirlilik analizi neticesinde ölçek üzerinde gerekli düzeltmeler yapılmış olup, 34 olan soru sayısı 32 ye indirilmiştir. Tüm faktör bazında Cronbach's Alpha değerleri “İşin Yapısı” için 0,881; “Örgüt Yapısı” için 0,673; “Örgütsel Politika" için 0,820; “Örgüt içi İlişkiler” için 0,854; "Fiziksel Koşullar” için 0,776 olarak oldukça yüksek güvenilirlik elde edilmiş ve daha sonra anket tüm sürücülere uygulanmıştır. Ölçeğin son hali Ek-3 te verilmiştir. 
Bu araştırmada evrenin tümü üzerinde çalışııış olup, 18/03/2016 ile 10/05/2016 tarihleri arasında EGO Genel Müdürlüğünde toplu taşıma hizmetinde sürücü olarak çahşan 2.137 çalşsanın tamamına ulaşılmaya çalşsılmıştır. EGO Genel Müdürlüğü; toplu taşıma hizmetini yürütmek amacıyla Ankara içi ulaşımı 5 farklı bölgeye ayırmış olup, her bir bölgede çalşan sürücü sayısı farklılk göstermektedir. Bölgelerde çalşan personel sayısı ile cevaplandırılan anket sayıları Tablo 4'te gösterilmek tedir.

Tablo 4: Sürücü Sayısı ve Anket Katılımı

\begin{tabular}{|c|c|c|c|c|}
\hline Bölge adı & Çalışılan Yer & $\begin{array}{c}\text { Çalışan } \\
\text { personel sayısı }\end{array}$ & $\begin{array}{c}\text { Cevaplan dirılan } \\
\text { Anket sayısı }\end{array}$ & $\begin{array}{c}\text { Katılan } \\
\text { pers onelin tüm } \\
\text { ankete oranı }\end{array}$ \\
\hline 1. Bölge Otobüs İşl. Şb. Mdr. & Çankaya & 264 & 190 & $12 \%$ \\
\hline 2. Bölge Otobüs İşl. Şb. Mdr. & Yenimahalle & 393 & 387 & $24 \%$ \\
\hline 3. Bölge Otobüs İşs. Şb. Mdr. & Mamak & 395 & 369 & $22 \%$ \\
\hline 4. Bölge Otobüs İşl. Şb. Mdr. & Altındağ & 449 & 408 & $25 \%$ \\
\hline 5. Bölge Otobüs İșl. Şb. Mdr. & Etimesgut & 636 & 283 & $17 \%$ \\
\hline Toplam & & 2.137 & 1.637 & $100 \%$ \\
\hline
\end{tabular}

Sürücü personelden oluşan ana kütlenin tamamına dağttlan 2.137 adet ölçeğin 1.637 tanesi cevaplandırılmışır. 83 adet anketin eksik veya tutarlı olmayacak şekilde doldurulduğu anlaşıldığından analiz kapsamından çıkarılmıştır. Dolayısıyla istatistik analizlerinde kullanılabilecek anket sayısı 1.554 olmuştur. $\mathrm{Bu}$ sayı evrenin \%72'lik kısmını temsil etmektedir. Araştırmada sürücülere uygulanan ölçekten elde edilen veriler SPSS (22) istatistik programı yardımıyla değerlendirilmiştir. Öncelikle ölçeğe verilen cevapların betimleyici istatistiksel değerleri analiz edilmiştir. Daha sonra faktör analizi, ilgili güvenirlilik analizi, ardından da bölge bazlı varyans analizi yapılmıştır. Bölgeler arasında anlamlı bir fark olup olmadı̆̆ incelenirken, bu incelemede üçten fazla grup bulunduğundan her ne kadar ANOVA analizi yapılmak istenmiş olsa da, ölçek homojen olmadığından alternatif analiz olan Welch, Brown-Forsythe testleri ve Tamhane analizleri yapılmıştır.

\section{ANALIZ VE BULGULAR}

\subsection{Betimleyici İstatistikler}

Örgütsel stres kaynaklarına ilişkin anketimizdeki sorulara verilen cevapların frekans ve ortalamaları ile ilgili bulguları Tablo 5'te özetlenmiştir. 
Tablo 5: Sürücülerin Örgütsel Stres Kaynakları ve Düzeyleri ile İlgili Betimsel İstatistikler

\begin{tabular}{|c|c|c|c|c|c|c|c|c|c|}
\hline \multirow{2}{*}{$\begin{array}{c}\text { Sira } \\
\text { No }\end{array}$} & \multirow[t]{2}{*}{ İfadeler } & & \multicolumn{5}{|c|}{ Katılım Düzeyi } & \multirow[t]{2}{*}{ Ort } & \multirow[t]{2}{*}{ s.s } \\
\hline & & & Hiç & $\overline{\mathrm{Az}}$ & Orta & Çok & Pek Çok & & \\
\hline 1 & İşin monoton ve sıkıcı olması & $\begin{array}{l}\mathrm{f} \\
\%\end{array}$ & $\begin{array}{r}219 \\
14,1\end{array}$ & $\begin{array}{r}264 \\
17,0\end{array}$ & $\begin{array}{r}491 \\
31,6\end{array}$ & $\begin{array}{r}295 \\
19,0\end{array}$ & $\begin{array}{l}285 \\
18,3\end{array}$ & 3,10 & 1,28 \\
\hline 2 & Çalışma saatlerinin uzun olması & $\mathrm{f}$ & $\begin{array}{r}173 \\
11,1\end{array}$ & $\begin{array}{r}170 \\
10,9\end{array}$ & $\begin{array}{r}497 \\
32,0\end{array}$ & $\begin{array}{r}406 \\
26,1\end{array}$ & $\begin{array}{l}308 \\
19,8\end{array}$ & 3,32 & 1,22 \\
\hline 3 & Servise zamanında başlama/bitirme baskısının olması & $\begin{array}{l}\mathrm{f} \\
\%\end{array}$ & $\begin{array}{l}127 \\
8,2\end{array}$ & $\begin{array}{r}169 \\
10,9\end{array}$ & $\begin{array}{r}385 \\
24,8\end{array}$ & $\begin{array}{r}365 \\
23,5\end{array}$ & $\begin{array}{l}508 \\
32,7\end{array}$ & 3,61 & 1,26 \\
\hline 4 & Aşırı iş yükünün olması & $\begin{array}{c}\mathrm{f} \\
\%\end{array}$ & $\begin{array}{l}105 \\
6,8\end{array}$ & $\begin{array}{l}125 \\
8,0\end{array}$ & $\begin{array}{r}368 \\
23,7\end{array}$ & $\begin{array}{r}453 \\
29,2\end{array}$ & $\begin{array}{l}503 \\
32,4\end{array}$ & 3,72 & 1,18 \\
\hline 5 & İstirahat sürelerinin az olması & $\begin{array}{l}\mathrm{f} \\
\%\end{array}$ & $\begin{array}{r}89 \\
5,7\end{array}$ & $\begin{array}{r}186 \\
12,0\end{array}$ & $\begin{array}{r}403 \\
25,9\end{array}$ & $\begin{array}{r}389 \\
25,0\end{array}$ & $\begin{array}{l}487 \\
31,3\end{array}$ & 3,64 & 1,20 \\
\hline 6 & Vardiyalı çalışma düzeninin olması & $\begin{array}{l}\mathrm{f} \\
\%\end{array}$ & $\begin{array}{c}202 \\
13,0\end{array}$ & $\begin{array}{c}194 \\
12,5\end{array}$ & $\begin{array}{r}457 \\
29,4\end{array}$ & $\begin{array}{r}339 \\
21,8\end{array}$ & $\begin{array}{c}362 \\
23,3\end{array}$ & 3,29 & 1,30 \\
\hline 7 & Vatandaş memnuniyetsizliği ve şikâyet edilme korkusu & $\begin{array}{l}\mathrm{f} \\
\%\end{array}$ & $\begin{array}{l}71 \\
4,6\end{array}$ & $\begin{array}{l}146 \\
9,4\end{array}$ & $\begin{array}{c}293 \\
18,9\end{array}$ & $\begin{array}{c}401 \\
25,8\end{array}$ & $\begin{array}{l}643 \\
41,4\end{array}$ & 3,90 & 1,17 \\
\hline 8 & İnsanlarla ve problemlerle sürekli uğraşmak & $\begin{array}{l}\mathrm{f} \\
\%\end{array}$ & $\begin{array}{c}72 \\
4,6\end{array}$ & $\begin{array}{l}114 \\
7,3\end{array}$ & $\begin{array}{c}285 \\
18,3\end{array}$ & $\begin{array}{r}386 \\
24,8\end{array}$ & $\begin{array}{l}697 \\
44,9\end{array}$ & 3,97 & 1,15 \\
\hline 9 & Sorumlulukların ağırlığı ya da çokluğu & $\begin{array}{c}\mathrm{f} \\
\%\end{array}$ & $\begin{array}{c}91 \\
5,9\end{array}$ & $\begin{array}{l}132 \\
8,5\end{array}$ & $\begin{array}{r}333 \\
21,4\end{array}$ & $\begin{array}{r}455 \\
29,3\end{array}$ & $\begin{array}{l}543 \\
34,9\end{array}$ & 3,78 & 1,17 \\
\hline 10 & Yapılan işle ilgili alınan kararlara katılamama & $\begin{array}{l}\mathrm{f} \\
\%\end{array}$ & $\begin{array}{c}167 \\
10,7\end{array}$ & $\begin{array}{r}197 \\
12,7\end{array}$ & $\begin{array}{r}418 \\
26,9\end{array}$ & $\begin{array}{r}413 \\
26,6\end{array}$ & $\begin{array}{c}359 \\
23,1\end{array}$ & 3,38 & 1,26 \\
\hline 11 & Yetki ve sorumluluklar arasında ki uyumsuzluklar & $\begin{array}{l}\mathrm{f} \\
\%\end{array}$ & $\begin{array}{l}136 \\
8,8\end{array}$ & $\begin{array}{r}222 \\
14,3\end{array}$ & $\begin{array}{r}436 \\
28,1\end{array}$ & $\begin{array}{r}372 \\
23,9\end{array}$ & $\begin{array}{c}388 \\
25,0\end{array}$ & 3,42 & 1,24 \\
\hline 12 & Çalışanlar ve bölümler arası aşırı rekabetin varlığı & $\begin{array}{l}\mathrm{f} \\
\%\end{array}$ & $\begin{array}{c}231 \\
14,9\end{array}$ & $\begin{array}{c}242 \\
15,6\end{array}$ & $\begin{array}{r}450 \\
29,0\end{array}$ & $\begin{array}{c}326 \\
21,0\end{array}$ & $\begin{array}{l}305 \\
19,6\end{array}$ & 3,14 & 1,31 \\
\hline 13 & $\begin{array}{l}\text { Örgüt yapısında rol, görev ve sorumlulukların dağlımındaki } \\
\text { bozukluklar }\end{array}$ & $\begin{array}{l}\mathrm{f} \\
\%\end{array}$ & $\begin{array}{r}182 \\
11,7\end{array}$ & $\begin{array}{r}204 \\
13,1\end{array}$ & $\begin{array}{r}399 \\
25,7\end{array}$ & $\begin{array}{r}374 \\
24,1\end{array}$ & $\begin{array}{l}395 \\
25,4\end{array}$ & 3,38 & 1,30 \\
\hline 14 & Maaş(ücret) adaletsizliği ve/veya düşüklüğü & $\begin{array}{c}\mathrm{f} \\
\%\end{array}$ & $\begin{array}{c}30 \\
1,9\end{array}$ & $\begin{array}{l}113 \\
7,3\end{array}$ & $\begin{array}{r}276 \\
17,8\end{array}$ & $\begin{array}{c}345 \\
22,2\end{array}$ & $\begin{array}{c}790 \\
50,8\end{array}$ & 4,12 & 1,06 \\
\hline 15 & Adaletsiz ödül, terfi ve başarı değerlendirmelerinin varlığı & $\mathrm{f}$ & $\begin{array}{l}123 \\
7,9\end{array}$ & $\begin{array}{r}168 \\
10,8\end{array}$ & $\begin{array}{r}343 \\
22,1\end{array}$ & $\begin{array}{r}410 \\
26,4\end{array}$ & $\begin{array}{l}510 \\
32,8\end{array}$ & 3,65 & 1,25 \\
\hline 16 & Sik sık görev yerinde değişiklik olması & $\begin{array}{l}\mathrm{f} \\
\%\end{array}$ & $\begin{array}{c}218 \\
14,4\end{array}$ & $\begin{array}{r}236 \\
15,2\end{array}$ & $\begin{array}{r}425 \\
27,3\end{array}$ & $\begin{array}{r}337 \\
21,7\end{array}$ & $\begin{array}{c}338 \\
21,8\end{array}$ & 3,21 & 1,32 \\
\hline 17 & Kendini geliştirme olanaklarının azlığı & $\begin{array}{l}\mathrm{f} \\
\%\end{array}$ & $\begin{array}{c}165 \\
10,6\end{array}$ & $\begin{array}{r}197 \\
12,7\end{array}$ & $\begin{array}{r}438 \\
28,2\end{array}$ & $\begin{array}{r}391 \\
25,2\end{array}$ & $\begin{array}{l}363 \\
23,4\end{array}$ & 3,37 & 1,26 \\
\hline 18 & Kurumun s1k1 kontrolve denetimleri & $\begin{array}{l}\mathrm{f} \\
\%\end{array}$ & $\begin{array}{l}145 \\
9,3\end{array}$ & $\begin{array}{r}183 \\
11,3\end{array}$ & $\begin{array}{r}515 \\
33,1\end{array}$ & $\begin{array}{r}400 \\
25,7\end{array}$ & $\begin{array}{l}311 \\
20,0\end{array}$ & 3,35 & 1,19 \\
\hline 19 & Cezalandırıcı değerlendirme sistemlerinin varlığı & $\begin{array}{c}\mathrm{f} \\
\%\end{array}$ & $\begin{array}{l}105 \\
6,8\end{array}$ & $\begin{array}{l}131 \\
8,4\end{array}$ & $\begin{array}{r}368 \\
23,7\end{array}$ & $\begin{array}{r}406 \\
26,1\end{array}$ & $\begin{array}{l}544 \\
35,0\end{array}$ & 3,74 & 1,21 \\
\hline 20 & Hizmet sözleşmesinin yenilenmeme/ işten çıkarılma korkusu & $\begin{array}{l}\mathrm{f} \\
\%\end{array}$ & $\begin{array}{r}80 \\
5,1\end{array}$ & $\begin{array}{l}105 \\
6,8\end{array}$ & $\begin{array}{r}275 \\
17,7\end{array}$ & $\begin{array}{r}312 \\
20,1\end{array}$ & $\begin{array}{l}782 \\
50,3\end{array}$ & 4,03 & 1,18 \\
\hline 21 & İşle ilgili yeterli eğitimin verilmemesi & $\begin{array}{l}\mathrm{f} \\
\%\end{array}$ & $\begin{array}{c}264 \\
17,0\end{array}$ & $\begin{array}{r}240 \\
15,4\end{array}$ & $\begin{array}{r}503 \\
32,4\end{array}$ & $\begin{array}{c}295 \\
19,0\end{array}$ & $\begin{array}{l}252 \\
16,2\end{array}$ & 3,01 & 1,29 \\
\hline 22 & Kaza anı ve sonrasında yeterli hukuki yardım alınamaması & $\begin{array}{l}\mathrm{f} \\
\%\end{array}$ & $\begin{array}{l}124 \\
8,0\end{array}$ & $\begin{array}{l}147 \\
9,5\end{array}$ & $\begin{array}{r}353 \\
22,7\end{array}$ & $\begin{array}{c}348 \\
22,4\end{array}$ & $\begin{array}{l}582 \\
37,5\end{array}$ & 3,71 & 1,27 \\
\hline 23 & Yapılan işte takdir edilmemek & $\begin{array}{l}\mathrm{f} \\
\%\end{array}$ & $\begin{array}{l}151 \\
9,7\end{array}$ & $\begin{array}{l}134 \\
8,6\end{array}$ & $\begin{array}{r}316 \\
20,3\end{array}$ & $\begin{array}{r}352 \\
22,7\end{array}$ & $\begin{array}{c}601 \\
38,7\end{array}$ & 3,71 & 1,31 \\
\hline 24 & İş yerinde dedikodunun varlığı & $\begin{array}{l}\mathrm{f} \\
\%\end{array}$ & $\begin{array}{c}106 \\
6,8\end{array}$ & $\begin{array}{r}180 \\
11,6\end{array}$ & $\begin{array}{c}307 \\
19,8\end{array}$ & $\begin{array}{c}351 \\
22,6\end{array}$ & $\begin{array}{c}610 \\
39,3\end{array}$ & 3,75 & 1,26 \\
\hline 25 & Amirler ile ilet işim güçlüğ̈̈/ yetersiz iletişim & $\begin{array}{l}\mathrm{f} \\
\%\end{array}$ & $\begin{array}{c}254 \\
16,3\end{array}$ & $\begin{array}{c}218 \\
14,0\end{array}$ & $\begin{array}{r}389 \\
25,0\end{array}$ & $\begin{array}{c}307 \\
19,8\end{array}$ & $\begin{array}{c}386 \\
24,8\end{array}$ & 3,22 & 1,39 \\
\hline 26 & İş ortamındaki sosyal ilişkilerin azlığı & $\begin{array}{l}\mathrm{f} \\
\%\end{array}$ & $\begin{array}{l}138 \\
8,9\end{array}$ & $\begin{array}{c}187 \\
12,0\end{array}$ & $\begin{array}{r}412 \\
26,5\end{array}$ & $\begin{array}{r}318 \\
20,5\end{array}$ & $\begin{array}{l}499 \\
32,1\end{array}$ & 3,54 & 1,29 \\
\hline 27 & $\begin{array}{l}\text { Yolcuların size zorbalık yapması, sözlü tacizde bulunması } \\
\text { ve/veya şiddet uygulaması }\end{array}$ & $\begin{array}{l}\mathrm{f} \\
\%\end{array}$ & $\begin{array}{r}60 \\
3,9\end{array}$ & $\begin{array}{r}91 \\
5,9\end{array}$ & $\begin{array}{r}290 \\
18,7\end{array}$ & $\begin{array}{r}384 \\
24,7\end{array}$ & $\begin{array}{l}729 \\
46,9\end{array}$ & 4,04 & 1,11 \\
\hline 28 & İşyerinde ki sorunlar için amir desteğinin eksikliği & $\begin{array}{c}\mathrm{f} \\
\%\end{array}$ & $\begin{array}{l}224 \\
14,4\end{array}$ & $\begin{array}{r}177 \\
11,4\end{array}$ & $\begin{array}{r}386 \\
24,8\end{array}$ & $\begin{array}{r}345 \\
22,2\end{array}$ & $\begin{array}{l}422 \\
27,2\end{array}$ & 3,36 & 1,36 \\
\hline 29 & $\begin{array}{l}\text { Kötü fiziksel çalışma koşulları (İş ortamının sıcaklığı, soğukluğı, } \\
\text { aydınlatması vb.) }\end{array}$ & $\begin{array}{c}\mathrm{f} \\
\%\end{array}$ & $\begin{array}{r}182 \\
11,7\end{array}$ & $\begin{array}{r}214 \\
13,8\end{array}$ & $\begin{array}{l}446 \\
28,7\end{array}$ & $\begin{array}{r}360 \\
23,2\end{array}$ & $\begin{array}{l}352 \\
22,7\end{array}$ & 3,31 & 1,28 \\
\hline 30 & Otobüsün körüklü ya da solo olması & $\begin{array}{l}\mathrm{f} \\
\%\end{array}$ & $\begin{array}{l}423 \\
27,2\end{array}$ & $\begin{array}{c}242 \\
15,6\end{array}$ & $\begin{array}{r}467 \\
30,1\end{array}$ & $\begin{array}{r}258 \\
16,6\end{array}$ & $\begin{array}{c}164 \\
10,6\end{array}$ & 2,67 & 1,31 \\
\hline 31 & Otobüsün kalabalık olması & $\begin{array}{l}\mathrm{f} \\
\%\end{array}$ & $\begin{array}{c}251 \\
16,2\end{array}$ & $\begin{array}{c}202 \\
13,0\end{array}$ & $\begin{array}{r}369 \\
23,7\end{array}$ & $\begin{array}{r}359 \\
23,1\end{array}$ & $\begin{array}{c}373 \\
24,0\end{array}$ & 3,25 & 1,37 \\
\hline 32 & İşyerinin uzak olması ve işyerine ulaşım güçlüğü & $\begin{array}{l}\mathrm{f} \\
\%\end{array}$ & $\begin{array}{r}383 \\
24,6\end{array}$ & $\begin{array}{c}272 \\
17,5\end{array}$ & $\begin{array}{r}407 \\
26,2\end{array}$ & $\begin{array}{r}210 \\
13,5\end{array}$ & $\begin{array}{l}282 \\
18,1\end{array}$ & 2,83 & 1,41 \\
\hline
\end{tabular}

Tablo 5 incelendiğinde; Toplu taşıma hizmetinde çalşsan sürücüleri en fazla etkileyen stres kaynakları sırasıyla; "Maaş (ücret) adaletsizliği ve/veya düşüklüğ̈̈” (4,12), "Yolcuların 
kendilerine zorbalık yapması, sözlü tacizde bulunması ve/veya şiddet uygulaması" $(4,04)$ ile "Hizmet sözleşmesinin yenilenmeme/ işten çıkarılma korkusu" $(4,03)$ olmuştur. Sürücüleri en az etkileyen stres kaynakları ise; "Otobüsün körüklü ya da solo olması” (2,67), "İşyerinin uzak olması ve işyerine ulaşım güçlüğü" $(2,83)$ ile "İşle ilgili yeterli eğitimin verilmemesi" $(3,01)$ olmuştur. Diğer stres kaynakları ise sürücülerde orta derecede $(3,10-3,97)$ stres yapmaktadir.

\subsection{Faktör Analizi}

Veri setinin uygunluğu açısından, $\operatorname{KMO}(0,963)$ ve Barlett $(0,000)$ testlerinin değerleri veri setinin faktör analizi yapmak için geçerli değerlere sahip bulunmuştur. Measures of Sampling Adequacy değerleri ise tek bir soru $(0,883)$ hariç 0,92 'nin üzerinde çkmıştrr. Dolayısı ile veri setinin faktör analizine uygunluğu ortaya konmuştur. Faktör analizi sonucu ve faktör bazında ilgili güvenilirlik değerleri Tablo 6'da özet halinde sunulmuştur.

Tablo 6: Örgütsel Stres Kaynakları Faktör Analizi Sonucu ve İlgili Güvenilirlik Değerleri

\begin{tabular}{|c|c|c|c|c|}
\hline Faktörün Adı & Soru İfadesi & $\begin{array}{c}\text { Faktör } \\
\text { A ğırlıkları }\end{array}$ & $\begin{array}{c}\text { Faktörün } \\
\text { Açıklayıcılığı } \\
\text { (varyans) }\end{array}$ & $\begin{array}{c}\text { Güve nilirlik } \\
\text { (Cronbach's } \\
\text { Alpha) } \\
\end{array}$ \\
\hline \multirow{11}{*}{$\begin{array}{l}\text { Ö rgütün ve İşin } \\
\text { Yapısı }\end{array}$} & İşin monoton ve sıkıcı olması & 0,735 & \multirow{11}{*}{17,596} & 0,900 \\
\hline & Çalıșma saatlerinin uzun olması & 0,678 & & \\
\hline & Servise zamanında başlama/ bitirme baskısının olması & 0,664 & & \\
\hline & Așırı iş yükünün olması & 0,642 & & \\
\hline & Vardiyalı çalışma düzeninin olması & 0,627 & & \\
\hline & Yapılan işle ilgili alınan kararlara katılamama & 0,625 & & \\
\hline & Yetki ve sorumluluklar arasında ki uyumsuzluklar & 0,623 & & \\
\hline & Çalışanlar ve bölümler arası aşırı rekabetin varlığı & 0,546 & & \\
\hline & $\begin{array}{l}\text { Örgüt yapısında rol, görev ve sorumlulukların } \\
\text { dağılımındaki bozukluklar }\end{array}$ & 0,538 & & \\
\hline & Sık sık görev yerinde değişiklik olması & 0,530 & & \\
\hline & Kendini geliştirme olanaklarının azlığı & 0,517 & & \\
\hline \multirow{7}{*}{$\begin{array}{l}\text { Ö rgütsel } \\
\text { Politikalar }\end{array}$} & Vatandaş memnuniyetsizliği ve şikâyet edilme korkusu & 0,749 & \multirow{7}{*}{14,247} & 0,825 \\
\hline & İnsanlarla ve problemlerle sürekli uğrașmak & 0,694 & & \\
\hline & Sorumlulukların ağırlığı ya da çokluğu & 0,630 & & \\
\hline & Maaş(ücret) adaletsizliği ve/veya düşüklüğü & 0,600 & & \\
\hline & Cezalandırıcı değerlendirme sistemlerinin varlığı & 0,521 & & \\
\hline & $\begin{array}{l}\text { Hizmet sözleşmesinin yenilenmeme/işten çıkarılma } \\
\text { korkusu }\end{array}$ & 0,507 & & \\
\hline & $\begin{array}{l}\text { Yolcuların size zorbalık yapması, sözlü tacizde } \\
\text { bulunması ve/veya şiddet uygulaması }\end{array}$ & 0,503 & & \\
\hline \multirow[t]{6}{*}{$\begin{array}{l}\text { Ö rgüt İçi } \\
\text { İliş kiler }\end{array}$} & $\begin{array}{l}\text { Kaza anı ve sonrasında yeterli hukuki yardım } \\
\text { alınamaması }\end{array}$ & 0,700 & \multirow[t]{6}{*}{12,735} & 0,869 \\
\hline & Yapılan işte takdir edilmemek & 0,699 & & \\
\hline & İşyerinde dedikodunun varlığı & 0,685 & & \\
\hline & Amirler ile iletişim güçlüğü/ yet ersiz iletişim & 0,645 & & \\
\hline & İşortamındaki sosyal ilişkilerin azlığı & 0,620 & & \\
\hline & İşyerinde ki sorunlar için amir dest eğinin eksikliği & 0,550 & & \\
\hline \multirow[t]{3}{*}{ Fiziksel Koşullar } & Otobüsün körüklü ya da solo olması & 0,774 & \multirow[t]{3}{*}{9,334} & \multirow[t]{3}{*}{0,736} \\
\hline & Otobüsün kalabalık olması & 0,764 & & \\
\hline & İşyerinin uzak olması ve işyerine ulaşım güçlüğü & 0,691 & & \\
\hline
\end{tabular}


Faktör analizinden önce hazurlanan ölçek 32 sorudan meydana gelmiştir. Faktör analizi neticesinde; soru-5, soru-15, soru-18, soru-21 ve soru-29 analiz dışı bırakılmış ve 32 sorudan oluşan ölçek 28 soruya inmiştir. Faktör analizi neticesinde ölçek toplam dört faktörden oluşmakta olup, varyansları incelendiğinde; birinci faktör toplam varyansın \%17,596'smı, ikinci faktör toplam varyansin \%14,247'sini, üçüncü faktör toplam varyansin \%12,735'ini, dördüncü faktör toplam varyansm \%9,334'ünü açklamaktadır. Bu dört faktör tüm ölçeğin \%53,912 varyansını oluşturmaktadır. Güvenirlilik analizi neticesinde; birinci faktörün alpha değeri 0,900, ikinci faktörün alpha değeri 0,825, üçüncü faktörün alpha değeri 0,869 , dördüncü faktörün alpha değeri 0,736 olarak bulunmuştur. Örgütsel Stres Kaynağı ölçeğinin geneli için hesaplanan alpha değeri 0,936 olarak hesaplanmıştır. $\mathrm{Bu}$ değere göre ölçeğin yüksek derecede güvenilir olduğu ortaya çıkmıştır.

Çahşsmada literatür taraması doğrultusunda ve toplu taşıma hizmetinde çahş̧an yöneticilerin ve katıllmmcıların görüşü alınarak hazırlanan ölçek beş faktörden oluşmuştur. Ancak yapılan faktör analizi neticesinde örgütsel yap1 ile işin yapıs1 bir faktörde birleştirilmiştir. Bunun sonucunda faktörler; “örgütün ve işin yapısı", “örgütsel politika”, “örgüt içi ilişkiler" ve "fiziksel koşullar" adları altında gruplandırılmış̧ır. Dolayısı ile bu iki faktörün bir arada değerlendirilmesi ile birlikte, ilgili literatür göz önünde bulundurularak hazırlanan faktör dağılımı ve faktör analizi neticesinde ortaya çıkan faktör dağılımının birbiri ile tutarh olduğu görülmüştür.

\subsection{Bölge Bazlı Varyans Analizi}

$\mathrm{Bu}$ aşamada toplu taşımada çalışan örgütsel stres düzeylerinin çalıştıkları bölgeye göre farklllk gösterip göstermediği analiz edilmiştir. Bölgeler arası varyans homojenliği sağlanmadığından, Levene's test ve ANOVA (Analysis of Variance) analizi yerine, bu gibi durumlarda alternatif olarak kullanılan Welch ve Brown-Forsythe testleri uygulanmış ve Tamhane analizleri yapılmıştır (Durmuş, 2016:132). Bu analizler sonucunda faktör bazında bölgelerin stres düzeyleri belirlenmiş olup tüm bölgelerin stres düzeyleri aşağıda Tablo 7'de verilmiştir.

Tablo 7: Çalşıllan Bölgeye Göre Welch ve Brown-Forsythe Analizleri

Statistic df1

df2 $\operatorname{Sig}(\mathbf{p})$ 


\begin{tabular}{lccccc}
\hline Örgütün ve İşin Yapısı & Welch & 55,168 & 4 & 667,862 & 0,000 \\
& Brown-Forsythe & 37,957 & 4 & 1168,725 & 0,000 \\
\hline Örgütsel Politikalar & Welch & 56,626 & 4 & 678,426 & 0,000 \\
& Brown-Forsythe & 52,233 & 4 & 1391,113 & 0,000 \\
\hline \multirow{2}{*}{ Örgüt İçi İlişskiler } & Welch & 37,822 & 4 & 682,334 & 0,000 \\
& Brown-Forsythe & 26,690 & 4 & 1328,426 & 0,000 \\
\hline \multirow{2}{*}{ Fiziksel Koşullar } & Welch & 3,535 & 4 & 673,742 & 0,007 \\
& Brown-Forsythe & 2,655 & 4 & 1261,643 & 0,032 \\
\hline
\end{tabular}

Bölgelerde çalışan sürücülerin stres düzeyleri sırasıyla; 1. Bölge $(3,66), 2$. Bölge $(3,62)$, 4. Bölge $(3,55)$, 3. Bölge $(3,30)$, 5. Bölge $(3,08)$ çıkmıştır. Tüm faktörler dikkate alındığında stres düzeyi, en yükssek olan 1.Bölge Şube Müdürlüğ̈̈ çalışanları olurken, stres düzeyi en düşük 5.Bölge Şube Müdürlüğü çalş̧anları olmuştur. Sürücülerin bölge bazh stres düzeyleri Tablo 8'de verilmiştir.

Tablo 8: Bölgelerin Karşılaştırmalı Stres Düzeyleri

\begin{tabular}{lccccc}
\hline \multirow{2}{*}{ Bölgeler } & \multicolumn{4}{c}{ Faktörler } & \multirow{2}{*}{ Ort. } \\
\cline { 2 - 5 } & İşin ve Örgütün Yapısı & Örgütsel Politikalar & Örgüt İçi İlişkiler & Fiziksel Koşullar & \\
1. Bölge & 3,54 & 4,15 & 3,94 & 3,04 & 3,66 \\
2. Bölge & 3,72 & 4,10 & 3,68 & 2,99 & 3,62 \\
\hline 3. Bölge & 3,11 & 3,84 & 3,34 & 2,91 & 3,30 \\
4. Bölge & 3,41 & 4,17 & 3,73 & 2,92 & 3,55 \\
\hline 5. Bölge & 3,02 & 3,41 & 3,17 & 2,75 & 3,08 \\
\hline
\end{tabular}

Sürücülerin stres düzeyini en fazla etkileyen faktörler sırasıyla; Örgütsel Politikalar, İşin ve Örgütün Yapısı, Örgüt İçi İlişkiler, Fiziksel Koşullar olmuştur. Sürücülerde en fazla stres yapan faktör örgütsel politikalar olurken, en az stres yapan faktör ise fiziksel koşullar olmuştur.

\section{SONUÇ VE ÖNERILLER}

$\mathrm{Bu}$ çalışmada örgütsel stres faktörlerinin sürücülerin stres düzeyleri üzerindeki etkileri değerlendirilmiştir. Çalışma, gerek binlerce yolcunun can ve mal güvenliği ile ilişkili olması, gerekse ulaşılan 1.554 kişilik veri setinin büyüklüğü açısından önem arz etmektedir.

Sürücüleri etkileyen en önemli örgütsel stres faktörü örgütsel politikalar olurken, ardından sırasıyla örgüt içi ilişkiler ile örgütün ve işin yapısı gelmektedir. Fiziksel koşullar ise sürücülerin stres düzeyini en az etkileyen faktör olmuştur. Sürücülerde en çok strese sebep olan durumlar; "maaş (ücret) adaletsizliği ve/veya düşüklüğü”, “yolcuların kendilerine zorbalk yapması, sözlü tacizde bulunması ve/veya şiddet uygulaması" ile "hizmet sözleşmesinin yenilenmeme/işten çıkarılma korkusu" olurken, en az strese sebep olan durumlar ise; "otobüsün körüklü ya da solo olması", "işyerinin uzak olması ve işyerine ulaşım 
güçlüğü" ile "işle ilgili yeterli eğitimin verilmemesi" olmuştur. Bölgeler arasında stres düzeyi en yükssek çıkan bölge 1.Bölge Otobüs İşletme Şube Müdürlüğü çalışanları olurken, stres düzeyi en düşük çıkan bölge ise 5.Bölge Otobüs İşletme Şube Müdürlüğü çalşanları olmuştur.

Çalşsmada tespit edilen stres kaynakları doğrultusunda, bu stres kaynaklarının daha etkin yönetilmesi için uygulamacıya yönelik öneriler aşağıda sunulmuştur:

a)Toplu taşıma hizmeti sunan sürücülerde en fazla strese sebep olan durum maaş adaletsizliği ve düşüklüğüdür. İşletme tarafindan sürücülerin ekonomik olarak daha rahat etmeleri için ekonomik koşullar da dikkate alınarak alınan ücret ve maaşlarla ilgili bir çalşsma yapılarak sürücülerin maaşlarında iyileştirme yapılabilir.

b) Sürücülerde en fazla strese sebep olan bir diğer etmen olan yolcularm sürücülere zorbalk yapması, sözlü tacizde bulunması veya şiddet uygulaması olarak ortaya konmuştur. $\mathrm{Bu}$ durumun engellenmesi amacıyla işletme tarafindan, sürücülere yeterli saygı gösterilmesi için özellikle medya vasitasılyla vatandaşlar bilgilendirilmelidir.

c) Uzman kişiler tarafindan; hem sürücülere hem amirlerine stresin ne olduğu, stresin ortaya çkardığı olumsuz sonuçlarının neler olduğu, hem bireysel stresin hem de örgütsel stresin nasıl optimal seviyede tutulacağı ile ilgili stres yönetimi eğitimi verilmeli, seminerler düzenlenmeli, ayrıca yoğun strese maruz kalan çalşanlara bireysel rehberlik hizmetleri sunulmalidir.

d) Alınan kararlarda sürücülerin görüşü dikkate alınmal,, yoğun strese maruz kalan sürücülere sosyal destek sağlanmalıdır.

e) Her bir bölge şube müdürlüğünde sürücülerin şikâyetlerini ve çalışma koşullarının iyileştirilmesine yönelik fikirlerini belirtebilecekleri formlar ve şikâyet kutuları oluşturulmalı, bu kutularda sürücülerin şikâyet ettikleri durumlar idareciler tarafindan dikkate alımmalı ve sürücülerde strese sebep olan durumlar çözüme kavuşturulmalıdır.

f) Amirler ile sürücüler arasında birlik ve beraberliği pekiştirecek, sosyal ilişkileri artıracak, iş ortaminda dedikoduları engelleyecek, çalışanların önemsendiği duygusunun oluşturulduğu bir ortamın yöneticiler tarafindan sağlanmahıdır. Yöneticiler; sürücüler arasında ayrım yapmamal, ücret, ödüllendirme, performans değerlendirme gibi durumlarda objektif davranmalı, adil ve adaletli olmalıdır.

Çalş̧ma, araştırmacilara yönelik olarak ise aşağıdaki konularda bundan sonraki araştirmalara 1ş1k tutabilir: 
a) $\mathrm{Bu}$ araştırma 2016 yllında Ankara Büyükşsehir Belediyesi bünyesinde çalşan sürücüleri kapsamaktadır. Örgütsel stres kaynakları ile ilgili anket çalşsmaları; ticari taksi, dolmuş, tramvay, metro veya diğer toplu taşıma hizmeti sunan sürücülere uygulanabilir.

b) Araştırma Ankara iliyle sinırlı tutulmuştur. Araştırma diğer illerde özellikle büyükşehirlerde toplu taşıma hizmeti sunan sürücülere uygulanabilir.

c) Konu ile ilgili olarak, bu araştırmada yer almayan idareciler veya araçların sevk ve idaresinde çalşan diğer personelde kapsam içine alını daha geniş bir araştırma yapilabilir.

d) Toplu taşıma hizmetinde çalşan sürücülere örgütsel stres kaynaklarının yanı sıra, demografik özellikleri de göz önünde bulundurularak sürücülerin; kişisel stres kaynakları, çevresel stres kaynakları, stres yönetiminin nasıl yapıldı̆̆ı gibi farklı değişkenler de eklenerek daha kapsamlı araştırma yapılabilir. 


\section{KAYNAKÇA}

Akhtar, M.M.S. (2011). The Nature and Sources of Organizational Stress: Some Coping Strategies. Journal Elementary Education, 21(2), 1-14.

Altunışık, R., Çoşkun, R., Yıldırım, E., Bayraktaroğlu, S. (2010). Sosyal Bilimlerde Araştırma Yöntemleri (6.Baskı). Sakarya: Sakarya Kitapevi.

Altuntaş, E. (2003). Stres Yönetimi, İstanbul: Alfa.

Arpacıŏlu, G. (2005). Türkiye'de Zorbalık Bir Çalışma Biçimi. Deniz Yalım (Ed.), İnsan Kaynaklarına Yeni Eğilimler, İstanbul: Hayat.

Arslan, M. (2010). Çalışma Yaşamında Stresin İş Tatmini Üzerindeki Etkisi ve Bir Araştırma. Marmara Üniversitesi, Sosyal Bilimler Enstitüsü, İstanbul.

Aslan, M. (1995). Öğretmenlerin Örgütsel Stres Kaynakları. İnönü Üniversitesi, Sosyal Bilimler Enstitüsü, Malatya.

Aydın, İ. (2012). Örgütsel Stres Kaynakları ve Yönetimi: Yozgat Emniyet Müdürlüğü Bünyesinde Bir Uygulama. Bozok Üniversitesi, SosyalBilimler Enstitüsü, Yozgat.

Aydın, İ.P. (2008). İş Yaşamında Stres. Ankara: Pegem.

Balcı, A. (2014). Çalışanlarda Stres Kaynakları, Stresle Başa Çıkma Yöntemleri ve Sağlık Sektörü. Beykent Üniversitesi, Sosyal Bilimler Enstitüsü, İstanbul.

Bakırc1, B. (2012). Ortaöğretim Kurumlarında Çalışan Öğretmenleri Etkileyen Örgütsel Stres Kaynaklanı Nelerdir? (Edirne İli Örneği). Trakya Üniversitesi, Sosyal Bilimler Enstitüsü, Edirne.

Baklacı, E. (2013). İş Stresi ve Tükenmişlik Arasındaki İlişki: Banka Çalışanları Üzerinde Bir Araştırma. Mustafa Kemal Üniversitesi, Sosyal Bilimler Enstitüsü, Hatay.

Baltaş, Z. ve Baltaş A. (2008). Stres ve Başa Çıkma Yolları (24.Bask1). İstanbul: Remzi.

Barutçugil, İ. (2002). Organizasyonlarda Duyguların Yönetimi. İstanbul: Kariyer.

Bayram, S. (2006). Örgütsel Stres Faktörleri ve Rehber Öğretmenler Üzerinde Bir Uygulama. Kocaeli Üniversitesi, Sosyal Bilimler Enstitüsü, İstanbul.

Bhatti, N. (2002). Causes of Stress in Organization, a Case Study of Sukkur, Canada, International Journal of Business and Management, 5(11), 3-14.

Budak, S. (2001). Psikoloji Sözlüğ̈̈. Ankara: Bilim ve Sanat. 
Cam, E. (2004). Çalışma Yaşamında Stres ve Kamu Kesiminde Kadın Çalışanlar. Uluslararası Insan Bilimleri Dergisi, 1303-5134,1-10.

Camkurt, M.Z. (2007). İşyeri Çalışma Sistemi ve İşyeri Fiziksel Faktörlerinin İş Kazaları Üzerindeki Etkisi. TÜHIS İs Hukuku ve İktisat Dergisi, 20(6)-21(1), Mayı/Ağustos, 80-106.

Can, H., (2011). Organizasyon ve Yönetim, Ankara: Siyasal.

Durmuş, B., Çinko, M., Yurtkoru, S., (2016). Sosyal Bilimlerde SPSS’le Veri Analizi (6. Baskı). İstanbul: Beta.

Ekinci, H. ve Ekici, S. (2003). Yöneticiler Üzerindeki Etkileri Açısından Stres Kaynakları ve Bir Uygulama. Uludă̈ Üniversitesi İI.̇.F. Dergisi, 22(2), 93-111.

Erdal, M.B. (2009). İşletmelerde Stres Kaynakları, Sonuçları ve Yönetim Teknikleri ve Bir Uygulama. Celal Bayar Üniversitesi, Sosyal Bilimler Enstitüsü Manisa.

Eren, E. (2015). Örgütsel Davranışve Yönetim Psikolojisi (15.Bask1). İstanbul, Beta Basım Yayım.

Eroğlu, F. (2000). Davranış Bilimler. İstanbul, Beta.

Ertekin, Y. (1993). Stres ve Yönetimi. Ankara, TODAİE.

Gamsız, Ş. (2013). Öğretmenlerde Stres Kaynakları, Öz Yeterlik, A Tipi Kişilik ve İş Doyumu. Karadeniz Teknik Üniversitesi, Eğitim Bilimler Enstitüsü, Trabzon.

Genç, N. (2005). Yönetim ve Organizasyon, Çă̆daş Sistemler ve Yaklaşımlar (2.Baskı). Ankara, Seçkin.

Güçlü, N. (2001). Stres Yönetimi. Gazi Fakültesi Ĕ̆itim Fakültesi Dergisi 21(1), 91-109.

Gümüştekin, G.E. ve Öztemiz, A.B. (2004). Örgütsel Stres Yönetimi ve Uçucu Personel Üzerinde Bir Uygulama. Erciyes Üniversitesi İI.I.B.F Dergisi, 23, 61-85.

Güney, G. (2015). Örgütsel Stres Kaynaklarının Çalışanlar Üzerine Etkileri ve Stres Yönetimi: Isparta Adliye Çalısanları Üzerine Bir Uygulama. Süleyman Demirel Üniversitesi, Sosyal Bilimler Enstitüsü, Isparta.

Güney, S. (2006). Davranış Bilimleri (3.Baskı). Ankara: Nobel.

Gürün, S. (2009). İşgören Stresinin, Motivasyon Üzerine Etkisi ve Bir Uygulama (Emniyet Teşkilatı). Beykent Üniversitesi, Sosyal Bilimler Enstitüsü, İstanbul.

Karasar, N. (2015). Araştırmalarda Rapor Hazırlama (19.Baskı). Ankara: Nobel. 
Kaya, E. (2006). Örgütsel Stres Kaynakları ve Akademisyenler Üzerine Bir Araştırma Örneği. Sakarya Üniversitesi, Sosyal Bilimler Enstitüsü, Sakarya.

Leka, S., Griffiths, A. ve Cox, T. (2005). Work Organization\&Stress, Systematic Problem Approaches For Employers, Managers And Trade Unıon Representatıves, Protecting Workers'Health Series 3., New Delhi, Institute Of Work, Health \&Organizations (WHO).

Madenoğlu, C. (2010). Eğitim Örgütü Yöneticilerinin Örgütsel Stres Kaynakları ve Stresle Başa Çıkma Tarzlarının Benlik Saygısı Düzeyleriyle Olan İlişkisi. Anadolu Üniversitesi, Sosyal Bilimler Enstitüsü, Eskişehir.

Merkan C. (2011). Genel Lise Anadolu Liselerinde Görevli Öğretmenlerin Stres Kaynaklarının Karşılaştırılmalı Analizi (Malatya İli Örneği), İnönü Üniversitesi, Eğitim Bilimler Enstitüsü, Malatya.

Michie, S., (2002). Causes And Management of Stress at Work, Occup Enviran Med, 59, 67-72.

Okutan, M. ve Tengilimoğlu, D. (2002). İş Ortamında Stres ve Stresle Başa Çıkma Yöntemleri: Bir Alan Uygulamas1. Gazi Üniversitesi İktisadi ve İdari Bilimler Fakültesi Dergisi, sayı:3, 15-42.

Özalp, Y.B. (2014). Öğretim Elemanlarında İş Stresine Neden Olan Örgütsel Etmenler ve Öğretim Elemanlarının Örgütsel Stresle Baş Etme Stratejileri (Trakya Üniversitesi Örneği). Osmangazi Üniversitesi, Eğitim Bilimleri Enstitüsü, Eskişehir.

Palmer, M.J. ve Hyman, B., (1993), Yönetimde Kadınlar, (çev: kurul), İstanbul, Rota.

Poyraz, E. (2009). İlköğretim ve Ortaöğretim Okulu Öğretmenlerin Örgütsel Stres Kaynakları ve Stresle Başa Çıkma Yolları. Yeditepe Üniversitesi, Sosyal Bilimler Enstitüsü, İstanbul.

Rawshan, A. (1998). Stres Yönetimi (Ş. Cüceloğlu, Çev.). İstanbul: Sistem.

Reisman A. (1992). Management Science Knowledge: It's Creation, Generalization and Consolidation.; Westport CT: Quorum Books.

Sabuncuoğlu, Z. (1987). Çalışma Psikolojisi. Bursa: Uludağ Üniversitesi.

Sabuncuoğlu, Z. ve Tüzün, M. (2001) Örgütsel Psikoloji. Bursa: Ezgi.

Sandıç̧ı, E. (2010). Stresin Tükenmişlik Boyutları Üzerindeki Etkisi: Diyarbakır'da Öğretmenler Üzerinde Bir Araştırma. Erciyes Üniversitesi, Sosyal Bilimler Enstitüsü, Kayseri.

Sayg1l, S. (1996). Strese Son. İstanbul: Elit.

Seyhan, N. (2007). Halk-Polis Karşılaşmasında Stres Faktörü Stad Örneği Uygulaması, Sakarya Üniversitesi, Sosyal Bilimler Enstitüsü, Sakarya. 
Silah, M. (2005). Endüstride Çalışma Psikolojisi (2.Bask1.). Ankara: Seçkin.

Soysal, A. (2009). İş Yaşamında Stres. Çimento İşveren Dergisi, 23(3), 17-40.

Stora, J.B. (1994). Stres (2.Baskı.). (K. Ayşen, Çev,) İstanbul: İletişim.

Şimşek, M.Ş., Akgemci, T. ve Çelik, A. (2008). Davranış Bilimleri Giriş ve Örgütlerde Davranış (6.Baskı.). Ankara: Gazi.

Turna, H. (2014). Öğretmenlerin Stres Kaynakları ve Stresle Başetme Yolları (Edirne İli-Keşan İlçesi Örneği). Okan Üniversitesi, Sosyal Bilimler Enstitüsü İstanbul.

Tutar, H. (2016). Kriz ve Stres Yönetimi. Ankara: Seçkin.

Yavuz, C. (2013). Sağlık Çalışanlarında İş Stresi: Çivril Devlet Hastanesi Örneği. Beykent Üniversitesi, Sosyal Bilimler Enstitüsü, İstanbul.

Yılmaz, A. ve Ekici, S. (2006). Örgütsel Yaşamda Kamu Çalışanlarının Örgütsel Stres Kaynakları Üzerine Bir Araştırma, Süleyman Demirel Üniversitesi İktisadi ve İdari Bilimler Fakültesi Dergisi, 11(1), 31-5 
Tablo 1: Taksonomi Yöntemiyle Literatür Taraması Özet Tablosu (Ek-1)

\begin{tabular}{|c|c|c|c|c|c|c|c|c|c|c|c|c|}
\hline & & & & & & & & $\mathrm{KON}$ & & ME] & & \\
\hline & & & & & & & $\underset{\overparen{D}}{\mathscr{D}}$ & 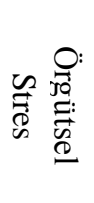 & 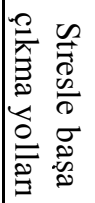 & 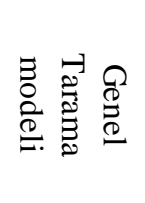 & 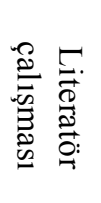 & \\
\hline No & Yazar & Y11 & Yayın & Baş lik & Türü & Sektör & & & & & & Sinırlilıklar \\
\hline 1 & Özalp, Y. B. & 2014 & Trakya Ü. & $\begin{array}{l}\text { Öğretim Elemanlarında İş Stresine Neden } \\
\text { Olan Örgütsel Etmenler ve Öğretim } \\
\text { Elemanlarının Örgütsel Stresle Baş Etme } \\
\text { Stratejileri (Trakya Üniversitesi Örneği) }\end{array}$ & Tez & Eğitim & + & + & + & + & + & $\begin{array}{c}\text { Trakya Üniversitesi 2011- } \\
2012 \text { yllında görev yapan } \\
\text { ögretim elemanlarına } \\
\text { uygulanmıştır. }\end{array}$ \\
\hline 2 & Aydın, İ.P. & 2008 & Pegem Y. & İş Yaşamında Stres & Kitap & Genel & + & + & & & & \\
\hline 3 & $\begin{array}{l}\text { Y1lmaz, A } \\
\text { v.d., }\end{array}$ & 2006 & $\begin{array}{l}\text { Süleyman Demirel } \\
\text { Ü. İ.İ.B.F Dergisi. }\end{array}$ & $\begin{array}{c}\text { Örgütsel Yaşamda Kamu Çalışanlarının } \\
\text { Örgütsel Stres Kaynakları Üzerine Bir } \\
\text { Araştırma }\end{array}$ & Makale & Ulaşım & + & + & & + & + & $\begin{array}{c}\text { Karayolları 16.Bölge } \\
\text { Müdürlügünde çalışan } \\
\text { personele uygulanmıştır. }\end{array}$ \\
\hline 4 & Bakırc1, B & 2012 & Trakya Ü. & $\begin{array}{l}\text { Ortaöğretim Kurumlarında Çalışan } \\
\text { Öğretmenleri Etkileyen Örgütsel Stres } \\
\text { Kaynakları Nelerdir? (Edirne İli Örneği) }\end{array}$ & Tez & Eğitim & + & + & + & + & + & $\begin{array}{l}\text { 2011-2012 yılında Edirne } \\
\text { ilindeki ortaöğretim } \\
\text { okullarına uygulanmıştır. }\end{array}$ \\
\hline 5 & $\begin{array}{l}\text { Gümüştekin, } \\
\text { G. E }\end{array}$ & 2004 & $\begin{array}{c}\text { Erciyes } \\
\text { Üniversitesi İ.İ.B.F }\end{array}$ & $\begin{array}{l}\text { Örgütsel Stres Yönetimi ve Uçucu } \\
\text { Personel Üzerinde Bir Uygulama, }\end{array}$ & Makale & Askeri & + & + & + & + & + & $\begin{array}{c}\text { Türk Silahlı Kuvvetlerine } \\
\text { Bağlı Uçucu Personele } \\
\text { uygulanmıştır. }\end{array}$ \\
\hline 6 & Michie, S & 2002 & $\begin{array}{l}\text { Occup Environ } \\
\text { Med. }\end{array}$ & Causes and Management of Stress at Work & Makale & Genel & + & + & & & + & \\
\hline 7 & Şimşek, M.Ş & 2008 & Gazi Kitapevi & $\begin{array}{c}\text { Davranış Bilimlerine Giriş ve Örgütlerde } \\
\text { Davranış }\end{array}$ & Kitap & Genel & & & & & & \\
\hline 8 & $\begin{array}{l}\text { Akhtar, } \\
\text { M.M. S }\end{array}$ & 2011 & $\begin{array}{l}\text { Journal Elementary } \\
\text { Education } \\
\end{array}$ & $\begin{array}{c}\text { The Nature and Sources of Organizational } \\
\text { Stress: Some Coping Strategies, }\end{array}$ & Makale & Genel & + & + & & & & \\
\hline 9 & Baklacı, E & 2013 & $\begin{array}{l}\text { Mustafa Kemal } \\
\text { Üniversitesi. }\end{array}$ & $\begin{array}{l}\text { İş Stresi ve Tükenmişlik Arasındaki İlişki: } \\
\text { Banka Çalışanları Üzerinde Bir Araştırma }\end{array}$ & Tez & Banka & + & + & & + & & $\begin{array}{c}\text { Hatay ilinde özel bir } \\
\text { bankada çalışan } 244 \\
\text { personele uygulanmıştır }\end{array}$ \\
\hline 10 & Eroğlu, F & 2000 & Beta Yayınları & Davranış Bilimler & Kitap & Genel & & & & & & \\
\hline 11 & Leka, v.d & 2004 & $\begin{array}{c}\text { Protecting } \\
\text { Workers'Health }\end{array}$ & Work Organization\&Stress & Makale & Genel & + & + & + & & & \\
\hline 12 & Stora, J.B. & 1994 & İletişim Yayınları & Stres & Kitap & Genel & + & + & + & & & \\
\hline 13 & Tutar, H. & 2016 & Seçkin Y. & Kriz ve Stres Yönetimi & Kitap & Genel & + & + & + & & & \\
\hline
\end{tabular}


Mehmet Zennur GÜRBÜZ, Göknur Arzu AKYÜZ

\begin{tabular}{|c|c|c|c|c|c|c|c|c|c|c|c|c|}
\hline 14 & Şimşek, Ş & 2002 & Gazi Kitapevi. & Yönetim ve Organizasyon & Kitap & Genel & & & & & & \\
\hline 15 & Bhatti, N & 2002 & $\begin{array}{l}\text { İnternational } \\
\text { Journal of } \\
\text { Business and } \\
\text { Management }\end{array}$ & $\begin{array}{c}\text { Causes of Stress in Organization, a Case } \\
\text { Study of Sukkur }\end{array}$ & $\begin{array}{c}\text { Maka } \\
\text { le }\end{array}$ & Genel & + & + & & & & \\
\hline 16 & Can, H. & 2011 & Siyasal Kitapevi & Organizasyon ve Yönetim & Kitap & Genel & + & + & & & & \\
\hline 17 & Balc1, A. & 2014 & $\begin{array}{l}\text { Beykent } \\
\text { Üniversitesi }\end{array}$ & $\begin{array}{c}\text { Çalışanlarda Stres Kaynakları, Stres le Başa } \\
\text { Çıkma Yöntemleri ve Sağlık Sektörü }\end{array}$ & Tez & Sağlik & + & + & & + & & \\
\hline 18 & Okutan, M. & 2002 & $\begin{array}{l}\text { Gazi Üniversitesi } \\
\text { İ.İ.B.F Dergisi }\end{array}$ & $\begin{array}{c}\text { İş Ortamında Stres ve Stresle Başa Çıkma } \\
\text { Yöntemleri: Bir Alan Uygulaması }\end{array}$ & $\begin{array}{c}\text { Maka } \\
\text { le }\end{array}$ & Ulaşım & + & + & + & + & & $\begin{array}{l}\text { T.C.D.D Ankara Bölge } \\
\text { Müdürlüğü Marşandiz Logo } \\
\text { Bakım Atölyelerinde çalışan } \\
300 \text { personele uygulanmıştır. }\end{array}$ \\
\hline 19 & Rawshan, A. & 1998 & Sistem Yayıncılik & Stres Yönetimi & Kitap & Genel & + & + & + & & & \\
\hline 20 & Palmer, M.J. & 1993 & Rota Yayıncılik & Yönetimde Kadınlar & Kitap & Genel & + & + & & & & \\
\hline 21 & Barutçugil, İ. & 2002 & Kariyer Yayınları & Organizasyonlarda Duyguların Yönetimi & Kitap & Genel & & + & + & & & \\
\hline 22 & Silah, M. & 2002 & Seçkin Yayınevi & Endüstride Çalışma Psikolojisi & Kitap & Genel & + & + & & & & \\
\hline 23 & Merkan, S. & 2011 & Malatya & $\begin{array}{c}\text { Genel Lise ve Anadolu Liselerinde Görevli } \\
\text { Öğretmenlerin Örgütsel Stres } \\
\text { Kaynaklarının Karşılaştırılmalı Analizi } \\
\text { (Malatya İli Örneği) }\end{array}$ & Tez & Eğitim & + & + & + & + & + & $\begin{array}{l}\text { Malatya İlinde } 5 \text { Anadolu } \\
\text { Lisesinde Çalışan } 246 \\
\text { Öğretmene Uygulanmıştır. }\end{array}$ \\
\hline 24 & Erdal, M.B. & 2009 & $\begin{array}{l}\text { Celal Bayar } \\
\text { Üniversitesi }\end{array}$ & $\begin{array}{l}\text { İşletmelerde Stres Kaynakları, Sonuçları ve } \\
\text { Yönetim Teknikleri ve Bir Uygulama }\end{array}$ & Tez & $\begin{array}{c}\text { Cam } \\
\text { Elyaf } \\
\text { İşletmesi }\end{array}$ & + & + & + & + & & $\begin{array}{c}\text { Cam Elyaf İşletmelerinde } \\
\text { çalışan } 403 \text { personele } \\
\text { uygulanmışır. }\end{array}$ \\
\hline 25 & Aslan, M. & 1995 & $\begin{array}{l}\text { İnönü } \\
\text { Üniversitesi }\end{array}$ & Öğretmenlerin Örgütsel Stres Kaynakları & Tez & Eğitim & + & + & + & + & & $\begin{array}{l}\text { 1993-1994 yılında Malatya } \\
\text { İl Merkezinde bulunan } 12 \\
\text { genel liseden } 469 \text { öğretmene } \\
\text { uygulanmiştır. }\end{array}$ \\
\hline 26 & Yavuz, C. & 2013 & $\begin{array}{c}\text { Beykent } \\
\text { Üniversitesi } \\
\end{array}$ & $\begin{array}{c}\text { Sağlık Çalı̧anlarında İş Stresi: Çivril } \\
\text { Devlet HastanesiÖrneği }\end{array}$ & Tez & Sağlik & + & + & + & + & & $\begin{array}{c}\text { Çivril Devlet Hastanesinde } \\
\text { çalışan } 104 \text { personele } \\
\text { uygulanmışır. }\end{array}$ \\
\hline 27 & $\begin{array}{l}\text { Arpacioğlu, } \\
\text { G. }\end{array}$ & 2005 & Hayat Yayıncılik & Türkiye'de Zorbalık Bir Çalışma Biçimi, & Kitap & Genel & & + & & & & \\
\hline 28 & $\begin{array}{l}\text { Sabuncuoğlu, } \\
\text { Z. }\end{array}$ & 1986 & $\begin{array}{l}\text { Uludağ } \\
\text { Üniversitesi } \\
\text { Basımevi } \\
\end{array}$ & Çalışma Psikolojisi & Kitap & Genel & & + & & & & \\
\hline 29 & Altuntaş, E. & 2003 & Alfa Basım Yayın & Stres Yönetimi & Kitap & Genel & + & + & + & & & \\
\hline
\end{tabular}


bmij (2017) 5 (2): 382-404

Tablo 1(devam): Taksonomi Yöntemiyle Literatür Taraması Özet Tablosu

\begin{tabular}{|c|c|c|c|c|c|c|c|c|c|c|c|c|}
\hline No & Yazar & Y1l & Yayın & Başlik & Türü & Sektör & & & & & & Sinırlilıklar \\
\hline 30 & Poyraz, E. & 2009 & $\begin{array}{l}\text { Yeditepe } \\
\text { Üniversitesi }\end{array}$ & $\begin{array}{c}\text { İlköğretim ve Ortaöğretim Okulu } \\
\text { Öğretmenlerin Örgütsel Stres Kaynakları ve } \\
\text { Stresle Başa Çıkma Yolları }\end{array}$ & Tez & Eğitim & + & + & + & + & & $\begin{array}{l}\text { 2007-2008 öğretim y1lında bursa } \\
\text { ilçelerinde görev yapan } 250 \\
\text { öğretmeni kapsamaktadır. }\end{array}$ \\
\hline 31 & Cam, E. & 2004 & $\begin{array}{l}\text { Uluslararas1 insan } \\
\text { bilimleri dergisi }\end{array}$ & $\begin{array}{l}\text { Çalışma Yaşamında Stres ve Kamu } \\
\text { Kesiminde Kadın Çalışanlar }\end{array}$ & Makale & Kamu & & & & + & & $\begin{array}{l}\text { Bilet kontrol dairesinde çalışan } 12 \\
\text { kadın personelden oluşmaktadır. }\end{array}$ \\
\hline 32 & Bayram, S. & 2006 & $\begin{array}{l}\text { Kocaeli } \\
\text { Üniversitesi }\end{array}$ & $\begin{array}{l}\text { Örgütsel Stres Faktörleri ve Rehber } \\
\text { Öğretmenler Üzerinde Bir Uygulama. }\end{array}$ & Tez & Eğitim & + & + & + & + & & $\begin{array}{l}\text { Kocaeli ilinde MEB'de görev } \\
\text { yapan } 121 \text { rehber öğretmenlere } \\
\text { uygulanmıştır. }\end{array}$ \\
\hline 33 & Turna, H. & 2014 & Okan Üniversitesi & $\begin{array}{c}\text { Öğretmenlerin Stres Kaynakları ve Stresle } \\
\text { Baş Etme Yolları (Edirne İli-Keşan İlçesi } \\
\text { Örneği) }\end{array}$ & Tez & Eğitim & + & + & + & + & + & $\begin{array}{l}\text { 2013-2014 öğretim yilında Edirne } \\
\text { Keşan ilçesinde görev yapan } 165 \\
\text { öğretmene uygulanmıştır. }\end{array}$ \\
\hline 34 & Genç, N. & 2005 & Seçkin Yayıncılık & $\begin{array}{l}\text { Yönetim ve Organizasyon, Çağdaş } \\
\text { Sistemler ve Yaklaşımlar } \\
\end{array}$ & Kitap & Genel & & & & & & \\
\hline 35 & Soysal, A. & 2009 & $\begin{array}{l}\text { Çimento İşveren } \\
\text { Dergisi } \\
\end{array}$ & İş Yaşamında Stres & Makale & Genel & + & + & + & & & \\
\hline 36 & Gürün, S. & 2009 & $\begin{array}{l}\text { Beykent } \\
\text { Üniversitesi. }\end{array}$ & $\begin{array}{l}\text { İşgören Stresinin, Motivasyon Üzerine } \\
\text { Etkisi ve Bir Uygulama (Emniyet Teşkilatı) }\end{array}$ & Tez & Emniyet & + & + & + & + & & $\begin{array}{c}\text { İstanbul Küçükçekmece ilçesinde } \\
\text { görev yapan } 116 \text { polise } \\
\text { uygulanmıştır. }\end{array}$ \\
\hline 37 & Baltaş, & 2008 & Remzi Kitapevi & Stres ve Başa Çıkma Yolları & Kitap & Genel & + & + & + & & & \\
\hline 38 & Kaya, E. & 2006 & $\begin{array}{l}\text { Sakarya } \\
\text { Üniversitesi }\end{array}$ & $\begin{array}{c}\text { Örgütsel Stres Kaynakları ve } \\
\text { Akademisyenler Üzerine Bir Araştırma } \\
\text { Örneği }\end{array}$ & Tez & Eğitim & + & + & + & + & & $\begin{array}{c}\text { Yeditepe, Doğuş ve Ondokuz } \\
\text { Mayıs Üniversitelerinde görevli } \\
100 \text { akademisyene uygulanmıştır. }\end{array}$ \\
\hline 39 & Arslan, M. & 2010 & $\begin{array}{l}\text { Marmara } \\
\text { Üniversitesi }\end{array}$ & $\begin{array}{l}\text { Çalış̧ma Yaşamında Stresin İş Tatmini } \\
\text { Üzerindeki Etkisi ve Bir Araştırma }\end{array}$ & Tez & Banka & + & + & + & + & & $\begin{array}{l}\text { İzmir ve İstanbul'da faaliyet } \\
\text { gösteren bankalarda çalışan } 136 \\
\text { personele uygulanmışır. }\end{array}$ \\
\hline 40 & Eren, E. & 2015 & Beta Yayınları & Örgütsel davranış ve yönetim psikolojisi & Kitap & Genel & & & & & & \\
\hline 41 & $\begin{array}{l}\text { Sandikçı, } \\
\text { E. }\end{array}$ & 2010 & $\begin{array}{l}\text { Erciyes } \\
\text { Üniversitesi }\end{array}$ & $\begin{array}{c}\text { Stresin Tükenmişlik Boyutları Üzerindeki } \\
\text { Etkisi: Diyarbakır'da Öğretmenler Üzerinde } \\
\text { Bir Araştırma }\end{array}$ & Tez & Eğitim & & & & + & & $\begin{array}{l}\text { Diyarbakır'da görev yapan } 498 \\
\text { ögretmene uygulanmıştır. }\end{array}$ \\
\hline 42 & Güney, S. & 2006 & $\begin{array}{l}\text { Nobel Yayın ve } \\
\text { Dağıtım }\end{array}$ & Davranış Bilimleri & Kitap & Genel & & & & & & . \\
\hline 43 & $\begin{array}{l}\text { Camkurt, } \\
\text { M.Z. }\end{array}$ & 2007 & $\begin{array}{l}\text { TÜHIS İs Hukuku } \\
\text { ve iktisat dergisi }\end{array}$ & $\begin{array}{l}\text { İsyeri Çalışma Sistemi ve İşyeri Fiziksel } \\
\text { Faktörlerinin İş Kazalanı Üzerindeki Etkisi }\end{array}$ & Makale & Genel & & & & & & \\
\hline
\end{tabular}


Tablo 2: Literatüre Göre Örgütsel Stres Kaynakları (Ek-2)

\begin{tabular}{|c|c|c|c|c|}
\hline \multicolumn{5}{|c|}{ Detaylandırılmış Örgütsel Stres Kaynakları } \\
\hline İşin Yapısı & Örgütsel Yapı & Örgüts el Politika & Örgüt İçi İliş kiler & Fiziksel Koşullar \\
\hline $\begin{array}{l}\text {-İşin monoton ve sıkıcı olması } \\
\text { (Şimşek v.d., 2008:339). } \\
\text {-I̧ste tehlike unsurunun varlığ1 } \\
\text { (Eroğlu, 2000:325). } \\
\text {-Yalnız çalışma (Leka, v.d., } \\
\text { 2014: 7). } \\
\text {-Güvensiz ortam (Akhtar, } \\
\text { 2011:4). } \\
\text {-Çalışma saatlerinin uzun } \\
\text { olması (Aydın, 2008:47). } \\
\text {-Sıkı ve esnek olmayan çalışma } \\
\text { programları (Leka, v.d., 2014: } \\
\text { 6). } \\
\text {-Öngörülemeyen çalışma } \\
\text { saatleri (Leka, v.d., 2014: 6). } \\
\text {-Zaman baskıs1 (Baklac1, } \\
\text { 2013:23-24). } \\
\text {-Aşırı iş yükü veya az çalışma } \\
\text { (Şimşek, 2002:318). } \\
\text {-Sorumlulukların ağırlığ1 ya da } \\
\text { çokluğu (Bhatti, 2010:5). } \\
\text {-Teknolojik değişimlere uyum } \\
\text { sağlayamama (Can, 2011:367). } \\
\text {-Vardiyalı çalışma düzeni } \\
\text { (Baltaş, v.d., 2008:83-84). } \\
\text {-Aile ve sosyalhayata yeteri } \\
\text { kadar zaman ayıramama } \\
\text { (Gümüştekin, 2004:61-85). } \\
\text {-Sürekli diğer insanlarla ve } \\
\text { diğer problemlerle uğraşmak } \\
\text { (Leka, v.d., 2014: 7). }\end{array}$ & $\begin{array}{l}\text {-Kararlara katılamama, yetki ve } \\
\text { sorumluluklar arasında } \\
\text { uyumsuzluklar (Bakırc1, } \\
\text { 2012:23). } \\
\text {-Merkeziyetçilik, aşırı bürokrasi } \\
\text { ve yazışmalar (Aydın, 2008:24). } \\
\text {-Kendini geliştirme } \\
\text { olanaklarının azlığ1 (Bakırc1, } \\
\text { 2012:23). } \\
\text {-Örgüt sınırları içinde çatışmalar } \\
\text { (Michie, 2002:68). } \\
\text {-Bölümler arası bağımlılık ve } \\
\text { çatışmalar (Eroğlu, 2000:348). } \\
\text {-I̧şle ilgili yeterli eğitimin } \\
\text { verilmemesi (Bakırcı, 2012:23). } \\
\text {-Kişiler ve bölümler arası aşırı } \\
\text { rekabet (Can, 2011:367). } \\
\text {-Örgütün yanlıs yönetim tarzı } \\
\text { (Balcı, 2014:42). } \\
\text {-Bürokratik engeller (Okutan, } \\
\text { v.d., 2002:8). } \\
\text {-Statü düşüklüğü, Örgüt } \\
\text { hiyerarşisinde yükselme hırsı ve } \\
\text { isteğgi (Rawshan, 1998:41). } \\
\text {-Kısıtlayıc1 ve güvensiz ortam } \\
\text { (Akhtar, 2011:4). }\end{array}$ & $\begin{array}{l}\text {-Maaş(ücret) adaletsizliği veya } \\
\text { düşüklüğü (Aydın, 2008:44). } \\
\text {-Adaletsiz ödül, terfi ve başarı } \\
\text { değerlemeleri (Palmer, v.d., } \\
\text { 1993:29). } \\
\text {-İş güvenliği eksikliği (Tutar, } \\
\text { 2016:235). } \\
\text {-Keyfi ve adaletsiz politikalar } \\
\text { (Bakırcı, 2012:23) } \\
\text {-Sik sık yer değiştirmeler } \\
\text { (Bakırc1, 2012:23) } \\
\text {-Rol belirsizliği (Barutçugil, } \\
\text { 2002:160). } \\
\text {-Rol çatışması (Silah, 2005:242) } \\
\text {-Adil olmayan denetçiler } \\
\text { (Aydın, 2008:52) } \\
\text {-Sikı kontrol (Akhtar, 2011:4). } \\
\text {-Kişiden beklenenin normalin } \\
\text { üstünde olmas1 (Bakırc1, } \\
\text { 2012:23). } \\
\text {-Organizasyonun hedefleri ve } \\
\text { yapısı hakkında netlik olmamas1 } \\
\text { (Leka, v.d., 2014: 7). }\end{array}$ & $\begin{array}{l}\text {-Yapılan işte takdir } \\
\text { edilmemek (Aydın, } \\
\text { 2008:53). } \\
\text {-Üstler, astlar ve } \\
\text { meslektaşlar arasında kötü } \\
\text { iliş kiler (Aydın, 2008:58). } \\
\text {-İş yerinde dedikodu } \\
\text { (Aydın, 2008:60). } \\
\text {-İletişim güçlüğ̈ü, yetersiz } \\
\text { iletişim (Erdal, 2009:114- } \\
\text { 115). } \\
\text {-İş ortamındaki sosyal } \\
\text { ilişkilerin azlığ1 (Aslan, } \\
\text { 1995:36). } \\
\text {-Zorbalık, taciz ve şiddet } \\
\text { (Yavuz, 2013:68). } \\
\text {-İşyerindeki sorunlar için } \\
\text { destek eksikliği (Leka, } \\
\text { v.d., 2014: 7). } \\
\text {-Ev ve işyeri arasında } \\
\text { çatışan talepler (Leka, } \\
\text { v.d., 2014: 7). } \\
\text {-Mobbing (Arpacıoğlu, } \\
\text { 2005:267). }\end{array}$ & $\begin{array}{l}\text {-Kötü fiziksel çalışma koşulları (İş } \\
\text { ortamının sıcaklığ1, aydınlatılması, } \\
\text { temizliği, çevresi v.b,) (Sabuncuoğlu, } \\
\text { 1986:55). } \\
\text {-Binanın aşırı büyüklüğü veya } \\
\text { küçüklüğü (Bakırcı, 2012:23). } \\
\text {-Aşırı ses ve gürültü (Aydın, 2008:49). } \\
\text {-Kalabalık ortamlar (Aydın, } \\
\text { 2008:49). } \\
\text {-İşyeri uzaklığ1 ve ulaşım güçlüğü } \\
\text { (Eren, 2015:268) } \\
\text {-̇̇ş için gerekli araç-gereç, laboratuar } \\
\text { eksikliği (Bakırc1, 2012:23). } \\
\text {-Zehirli kimyasallar ve radyasyon } \\
\text { (Camkurt, 2007:93-103). }\end{array}$ \\
\hline
\end{tabular}




\section{Toplu Tașımada Örgütsel Stres Kaynaklan Anket Formu (Ek-3 Anket)}

\section{Değerli Sürücü;}

Yaşamınızın önemli bir bölümünü geçirdiğiniz iş ortamında, gerek iş koşulları, gerek iş ilişkileri, gerekse de istihdam koşullarından dolayı ortaya çıkan stres belirli bir düzeyi aştığında sağlığınızı olumsuz etkilemektedir. $\mathrm{Bu}$ araştırma toplu taşıma hizmetinde çalışan siz sürücülerin; maruz kaldığı örgütsel stres kaynaklarını belirlemek, değerlendirmek ve gerekli önlemlerin alınmasını sağlamak için hazırlanmıştır. Verilen bu anketi yanıtlayarak çalışmaya katkı sağlayabilirsiniz. Anket formunu doldururken isim belirtmenize gerek yoktur. Doldurulan anketler bireysel olarak değerlendirilmeyecek olup, sadece yüksek lisans tezinde bilimsel amaçlı olarak kullanılacaktır. Değerli zamanınızı bize ayırdığınız için siz kıymetli sürücülerimize teşekkür ederim.

\section{Mehmet Zennur GÜRBÜZ \\ Müfettis}

Sayın sürücü işiniz ile ilgili olarak aşağıda belirtilen husus lar sizde ne derecede stres yaratmaktadır.

\begin{tabular}{|c|c|c|c|c|c|c|}
\hline & & Hiç & $\overline{A z}$ & Orta & Çok & Pek çok \\
\hline 1 & İşin monoton ve sıkıcı olması & 1 & 2 & 3 & 4 & 5 \\
\hline 2 & Çalışma saatlerinin uzun olması & 1 & 2 & 3 & 4 & 5 \\
\hline 3 & Servise zamanında başlama/bitirme baskısının olması & 1 & 2 & 3 & 4 & 5 \\
\hline 4 & Aşır1 iş yükünün olmas1 & 1 & 2 & 3 & 4 & 5 \\
\hline 5 & İstirahat sürelerinin az olmas1 & 1 & 2 & 3 & 4 & 5 \\
\hline 6 & Vardiy alı çalışma düzeninin olması & 1 & 2 & 3 & 4 & 5 \\
\hline 7 & Vatandaş memnuniy etsizliği ve şikây et edilme korkusu & 1 & 2 & 3 & 4 & 5 \\
\hline 8 & İnsanlarla ve problemlerle sürekli uğraşmak & 1 & 2 & 3 & 4 & 5 \\
\hline 9 & Sorumlulukların ağırlı̆ı ya da çokluğu & 1 & 2 & 3 & 4 & 5 \\
\hline 10 & Yapılan işle ilgili alınan kararlara katılamama & 1 & 2 & 3 & 4 & 5 \\
\hline 11 & Yetki ve sorumluluklar arasında ki uyumsuzluklar & 1 & 2 & 3 & 4 & 5 \\
\hline 12 & Çalışanlar ve bölümler arası aşırı rekabetin varlı̆̆ı & 1 & 2 & 3 & 4 & 5 \\
\hline 13 & Örgüt yapısında rol, görev ve sorumlulukların dağılımındaki bozukluklar & 1 & 2 & 3 & 4 & 5 \\
\hline 14 & Maaş(ücret) adaletsizliği ve/veya düşüklüğ̈̈ & 1 & 2 & 3 & 4 & 5 \\
\hline 15 & Adaletsiz ödül, terfi ve başarı değerlendirmelerinin varlı̆̆ & 1 & 2 & 3 & 4 & 5 \\
\hline 16 & S1k sı görev yerinde değişiklik olması & 1 & 2 & 3 & 4 & 5 \\
\hline 17 & Kendini geliştirme olanaklarının azlığı & 1 & 2 & 3 & 4 & 5 \\
\hline 18 & Kurumun s1k1 kontrol ve denetimleri & 1 & 2 & 3 & 4 & 5 \\
\hline 19 & Cezalandırıcı değerlendirme sistemlerinin varlığı & 1 & 2 & 3 & 4 & 5 \\
\hline 20 & Hizmet sözleşmesinin yenilenmeme/ işten ç1karılma korkusu & 1 & 2 & 3 & 4 & 5 \\
\hline 21 & İşle ilgili yeterli eğitimin verilmemesi & 1 & 2 & 3 & 4 & 5 \\
\hline 22 & Kaza anı ve sonrasında y eterli hukuki yardım alınamaması & 1 & 2 & 3 & 4 & 5 \\
\hline 23 & Yapılan işte takdir edilmemek & 1 & 2 & 3 & 4 & 5 \\
\hline 24 & İş yerinde dedikodunun varlığı & 1 & 2 & 3 & 4 & 5 \\
\hline 25 & Amirler ile iletişim güçlüğü/ y etersiz iletişim & 1 & 2 & 3 & 4 & 5 \\
\hline 26 & İş ortamındaki sosyal ilişkilerin azlığı & 1 & 2 & 3 & 4 & 5 \\
\hline 27 & $\begin{array}{l}\text { Yolcuların size zorbalık yapmas1, sözlü tacizde bulunmas1 ve/veya şiddet } \\
\text { uy gulamas1 }\end{array}$ & 1 & 2 & 3 & 4 & 5 \\
\hline 28 & İşy erinde ki sorunlar için amir desteğinin eksikliği & 1 & 2 & 3 & 4 & 5 \\
\hline 29 & $\begin{array}{l}\text { Kötü fiziksel çalışma koşulları (İş ortamının sıcaklığı, soğukluğu, } \\
\text { aydınlatması vb.) }\end{array}$ & 1 & 2 & 3 & 4 & 5 \\
\hline 30 & Otobüsün körüklü ya da solo olması & 1 & 2 & 3 & 4 & 5 \\
\hline 31 & Otobüsün kalabalık olmas1 & 1 & 2 & 3 & 4 & 5 \\
\hline 32 & İşy erinin uzak olması ve işy erine ulaşım güçlüğü & 1 & 2 & 3 & 4 & 5 \\
\hline
\end{tabular}

